\title{
Vegetation of the Hantam-TAnQuA-RoggeVeld Subregion, SOUTH AFrica Part 2: Succulent Karoo Biome Related vegetation
}

\author{
HELGA VAN DER MERWE \\ MARGARETHA W. VAN ROOYEN \\ NOEL VAN ROOYEN \\ Department of Plant Science \\ University of Pretoria \\ South Africa
}

Correspondence to: Helga van der Merwe

e-mail: soekop@hantam.co.za

Postal address: Department of Plant Science, University of Pretoria, Pretoria, 0002, South Africa

\begin{abstract}
The Hantam-Tanqua-Roggeveld subregion lies within the Succulent Karoo Hotspot that stretches along the western side of the Republic of South Africa and Namibia. This project, carried out to document the botanical diversity in the Hantam-Tanqua-Roggeveld subregion, was part of a project identified as a priority during the SKEP (Succulent Karoo Ecosystem Programme) initiative in this Hotspot. Botanical surveys were conducted in an area covering over three million hectares. Satellite images of the area and topocadastral, land type and geology maps were used to stratify the area into relatively homogeneous units. An analysis of the floristic data of 390 sample plots identified two major floristic units, i.e. the Fynbos Biome related vegetation and the Succulent Karoo Biome related vegetation. A description of the vegetation related to the Succulent Karoo Biome is presented in this article. Seven associations, 16 subassociations and several mosaic vegetation units, consisting of more than one vegetation unit, were identified and mapped. Various threats to the vegetation in the region were identified during the survey and are briefly discussed.
\end{abstract}

Keywords: Hantam, phytosociology, Roggeveld, Succulent Karoo, Tanqua Karoo, vegetation map, Western Mountain Karoo

The Succulent Karoo (CEPF 2003) stretches along the western side of South Africa and Namibia and is one of only two global hotspots that are entirely arid (Conservation International 2006). Within this area the Succulent Karoo Ecosystem Plan (SKEP) identified the Hantam-Tanqua-Roggeveld subregion as an area for which there is little information on the floral diversity, and consequently the Critical Ecosystem Partnership Fund (CEPF) funded botanical studies in the subregion.

The Hantam-Tanqua-Roggeveld subregion occurs where three biomes, namely the Fynbos, Succulent Karoo and the Nama Karoo Biomes (Rutherford \& Westfall 1986) meet. Due to the transitional nature of the area there has been some controversy as to whether the vegetation, especially that of the Roggeveld, should be classified as Fynbos or Succulent Karoo. The transitional nature of the subregion is supported in a recent study by Born et al. (2007) who argue for the recognition of a Greater Cape Floristic Region. The Fynbos related vegetation, or fire-prone vegetation within the subregion, is discussed by Van der Merwe et al. (2008). This article will focus on the Succulent Karoo related vegetation, which is not fire-prone.

Only a few studies have been conducted in the area, most of which were concentrated in the Nieuwoudtville area. Amongst these was a study by Snijman and Perry (1987) on the floristics of the Nieuwoudtville Wild Flower Reserve and the conservation farming project of the former National Botanical Institute (now the South African National Biodiversity Institute, SANBI), resulting in a host of research projects in the Nieuwoudtville area (South African National Biodiversity Institute, 2006). The Tanqua Karoo has been less studied than the Nieuwoudtville area, although a phytosociological study was conducted in the Tankwa National Park by Rubin (1998). However, the park subsequently substantially extended its boundaries beyond the area included in Rubin's original study.

Hilton-Taylor (1994) considered the subregion as part of the Succulent Karoo Biome. He identified two centres of endemism within the Western Cape Domain, viz. the Western Mountain Karoo and Tanqua Karoo, both of which occur within the area covered in this article. The botanical importance of the Hantam-Roggeveld was also emphasised by Van Wyk and Smith (2001). They identified the Hantam-Roggeveld as one of their 13 principal centres of plant endemism in southern Africa and also classified it as part of the Succulent Karoo Biome.

In this study a broad-scale vegetation survey of the entire subregion of approximately 3000000 ha $\left(30000 \mathrm{~km}^{2}\right)$ was undertaken. Analysis of the data revealed two distinct vegetation clusters. The first cluster, predominantly Mountain Renosterveld, is related to the Fynbos Biome, and is described in Van der Merwe et al. (2008). The aim of the present paper is to present a phytosociological analysis and description of the second vegetation cluster, i.e. the vegetation related to the Succulent Karoo Biome, and to create a map depicting the different vegetation units. A brief discussion of the various threats to the region as identified by the farming community and the Northern Cape Department of Agriculture, and through personal observations, is presented.

\section{STUDY AREA}

The Hantam-Tanqua-Roggeveld subregion (see figure of subregion in Van der Merwe et al. 2008) lies in the predominantly winter rainfall region of the Northern and Western Cape provinces of South Africa. In the south it stretches from the Ceres Karoo, where the Swartrug and Bontberg Mountains meet, northwards into the Tanqua Basin. The eastern border includes the Hantam, Roggeveld, Komsberg, Klein Roggeveld and Nuweveld Mountains to just southwest of Fraserburg, while the Cederberg and Bokkeveld Mountains to just north of Loeriesfontein form the western boundary.

The smaller study area discussed in this paper covers parts of the Hantam region, the Tanqua and Ceres Karoo regions 
as well as the area east of the Roggeveld Mountains. This area includes two of Acocks's veld types (Acocks 1953, 1988), namely: Succulent Karoo (Veld Type 31) and Western Mountain Karoo (Veld Type 28). These two veld types of Acocks are equivalent to the Lowland Succulent Karoo (Unit 57) and Upland Succulent Karoo (Unit 56) of Low and Rebelo (1998), respectively. Mucina et al. (2005) recognised the following large vegetation types in the study area: Hantam Karoo (SKt 2), Roggeveld Karoo (SKt 3), Tanqua Escarpment Shrubland (SKv 4), Tanqua Karoo (Skv 5), Tanqua Wash Riviere (AZi 7) and Namaqualand Riviere (AZi 1). Smaller patches of Nieuwoudtville Roggeveld Dolerite Renosterveld (FRd 1), Hantam Plateau Dolerite Renosterveld (FRd 2), Nieuwoudtville Shale Renosterveld (FRs 2) and Bushmanland Vloere (AZi 5) are also mapped in the area.

The physical geography of the region differs greatly. From the level plains of the Tanqua Karoo the landscape in the east rises steeply up the escarpment to the plateau formed by the Roggeveld, Komsberg, Koedoesberg and Nuweveld Mountains. The Hantam is characterised by a gently undulating to a steeply rolling topography.

Geologically, the Beaufort and Ecca Groups dominate the study area (Rubidge \& Hancox 1999, Council for Geoscience 1973, 1983, 1989, 1991, 1997, 2001, 2008). The Ecca Group covers most of the study area, with the Dwyka Group (tillite, sandstone, mudstone and shale) cropping out in the west. The Ecca Group includes sediments of the Tierberg (shale), Prince Albert (mudrock), Kookfontein (shale, siltstone and stone) and Skoorsteenberg Formations (mudstone, siltstone and sandstone). The mudstones of the Abrahamskraal Formation in the Beaufort Group are found on the eastern side of the study area, while igneous intrusions of dolerite occur throughout the region. An array of land types is represented in the study area (Agricultural Research Council 1986a, 1986b, 1995, 1999a, 1999b, 2002, 2003). The prominent land types include $\mathrm{Ag}, \mathrm{Da}, \mathrm{Dc}, \mathrm{Fb}, \mathrm{Fc}$, Ia and $\mathrm{Ib}$ (Du Plessis 1987).

Rainfall ranges from 50 to $300 \mathrm{~mm}$ a year, with a mean of $228 \mathrm{~mm}$, as measured at Calvinia (SA Weather Bureau 1998). Although the rain falls mainly in winter it does include a few summer thunderstorms. The highest annual rainfall, measured over a 29-year period, at Calvinia, was $472 \mathrm{~mm}$ in 1976 (SA Weather Bureau 1998). January and February have a mean maximum temperature of $30.8^{\circ} \mathrm{C}$ while an extreme maximum of $41.2^{\circ} \mathrm{C}$ was recorded in February 1990. The coldest months are June and July with a mean maximum of $17.1^{\circ} \mathrm{C}$ and $17.2^{\circ} \mathrm{C}$ respectively. The lowest temperature recorded was $-6.5^{\circ} \mathrm{C}$ in June 1978 (SA Weather Bureau 1998).

\section{METHODS AND MATERIALS}

On the basis of the colour, texture and topography, satellite images (Bands: 4,5,3 (R,G,B)) of the study area were visually stratified into relatively homogeneous units. Floristic surveys were carried out during the spring of 2004 at 390 sites selected in the stratified homogeneous units close to any national or provincial road or farm track. Plot sizes $10 \times 10 \mathrm{~m}$ were used in most of the surveys but larger plots $(20 \times 20 \mathrm{~m})$ were used in more denuded areas (Rubin 1998). Global Positioning System (GPS) coordinates were taken at each site. A cover-abundance value, according to the Braun-Blanquet scale (Werger 1974), was noted for each species present in a plot. Aspect, slope, position in the landscape, soil type and colour, an estimation of rock cover, rock size and erosion were noted at each sampling point. Rock size was categorised into gravel $(<10 \mathrm{~mm})$, small stones $(10-50 \mathrm{~mm})$, stones $(>50-200 \mathrm{~mm})$ and boulders (> $200 \mathrm{~mm})$. Trampling, small mammal activity and invasion by alien plants were some of the biotic effects also recorded.

Using the TURBOVEG and MEGATAB computer package an analysis of the floristic data was conducted (Hennekens \&
Schaminée 2001). TURBOVEG software was used to capture the vegetation data and a TWINSPAN (Two Way Species Indicator Analysis (Hill 1979)) was run in MEGATAB as a first step to the classification of the vegetation data. The result of the TWINSPAN (Two Way Species Indicator Analysis (Hill 1979)) on the entire data set of 390 relevés confirmed the presence of two distinct floristic groups, which enabled the data set to be split into two, and a TWINSPAN was then run on each data set separately. The resulting differential tables were further refined using Braun-Blanquet procedures. The first data set (107 relevés) characterised the vegetation of the predominantly Mountain Renosterveld with Fynbos affinities, and is described by Van der Merwe et al. (2008). The second data set (283 relevés) characterised the vegetation with predominantly Succulent Karoo affinities and is discussed further in this article.

The basic unit used here in the classification of the vegetation is the association. An association, as defined by Nelder et al. (2005), describes vegetation units on the basis of the presence and abundance of species, vegetation structure and spatial distribution of individuals in the dominant layer. Species within a subdominant structural layer and their canopy cover are used to describe the subassociations.

Associations and subassociations were mapped using the botanical survey data as well as 1:250 000 topocadastral maps, land type maps, geology maps (and electronic information supplied by the Council of Geoscience, 2008), and satellite images. Several mosaic units, which include more than one association or subassociation due to the transitional nature of the area, were also identified and mapped. (An electronic ArcView compatible version (raster or vector format) of the vegetation map is available from the authors on request. The pdf version provided here should best be printed to A3.)

Herbarium specimens were sent to Compton Herbarium, Kirstenbosch, for identification if identification of species in the field was in doubt. The collection code (HR) and numbers of the specimens were kept throughout the process. All the species, especially within the Aizoaceae (Mesembryanthemaceae), have not yet been positively identified. The H.G.W.J. Schweickerdt Herbarium (PRU), University of Pretoria, houses the voucher specimens collected. Nomenclature follows that of Germishuizen and Meyer (2003).

\section{RESULTS}

The phytosociological analysis of the floristic data is given in Tables $1 \mathrm{a}, 1 \mathrm{~b}$ and $1 \mathrm{c}$. In order to prevent confusion and to aid in the compilation of a vegetation map of the entire subregion the plant associations have been numbered sequentially following the three associations (1-3) described in Part 1 of this series (Van der Merwe et al. 2008). Seven associations were identified in the area under discussion and these were subdivided into 16 subassociations, as set out in the following scheme:

4. Pteronia glauca - Euphorbia decussata Escarpment Karoo 4.1 Montina caryophyllacea - Pteronia glauca Roggeveld Escarpment Karoo

4.2 Galenia africana - Pteronia glauca Escarpment Karoo

4.3 Euphorbia decussata-Ruschia cradockensis Escarpment Karoo

5. Eriocephalus purpureus Hantam Karoo

5.1 Erodium cicutarium - Eriocephalus purpureus Hantam Karoo

5.2 Ruschia cradockensis - Eriocephalus purpureus Hantam Karoo

5.3 Leipoldtia schultzei - Eriocephalus purpureus Hantam Karoo

6. Pteronia glomerata Roggeveld Karoo

6.1 Phyllobolus tenuiflorus - Pteronia glomerata Roggeveld Karoo

6.2 Eriocephalus pauperrimus - Pteronia glomerata Roggeveld Karoo 
6.3 Pentzia incana - Pteronia glomerata Roggeveld Karoo 6.4 Ruschia intricata - Pteronia glomerata Roggeveld Karoo

6.5 Eriocephalus ericoides - Pteronia glomerata Roggeveld Karoo

7. Aridaria noctiflora Tanqua and Loeriesfontein Karoo

7.1 Ruschia robusta - Aridaria noctiflora Tanqua Karoo

7.2 Drosanthemum (HR217) sp. - Aridaria noctiflora Tanqua Karoo

7.3 Malephora crassa - Aridaria noctiflora Tanqua Karoo

7.4 Atriplex lindleyi - Aridaria noctiflora Loeriesfontein Karoo

7.5 Ruschia intricata - Aridaria noctiflora Tanqua Karoo

8. Stipagrostis obtusa Central Tanqua Grassy Plains

9. Mesembryanthemaceae (HRp359) sp. Ceres Karoo Vygieveld

10. Pteronia (HRp118) sp. Tanqua Brackish Flats

Two vegetation units falling outside the present study area have been included in Table 1a. With the exception of these units and associations 9 and 10 all vegetation units could be mapped (Fig. 1). Ten mosaics found in areas where the landscape is spatially diverse were also mapped. The vegetation units making up the mosaics and the most important environmental features distinguishing the units are set out below:

- the Nieuwoudtville mosaic consists of vegetation units 2.1.1, 2.1.4, 2.2 of the Mountain Renosterveld vegetation (Van der Merwe et al. 2008.) and 5.1 predominantly found on the dolerite outcrops;

- the Grootfontein mosaic consists of vegetation units 4.2, 4.3 on undulating ridges and 5.1 and 5.2 on dolerite outcrops and dolerite derived soils;

- the Houhoek mosaic consists of vegetation unit 4.1 at a higher altitude and higher rock cover and unit 4.3 at a lower altitude and lower rock cover;

- the Adamsfontein/Noodsaaklikheid mosaic with vegetation unit 5.2 predominantly on dolerites and 6.5 on shales and dolerite intrusions that have been disturbed;

- the Calvinia mosaic consists of vegetation units 6.5 on Ecca shales and dolerite intrusions and 7.4 on brackish soils (historically overutilised);

- the Kalkgat mosaic consists of vegetation units 4.1 on rocky ridges, 7.2 on shales and sedimentary deposits and 7.3 on brackish soils;

- the Tanqua Karoo Inselberg mosaic with vegetation unit 5.2 on dolerites and 7.5 on Ecca shales;

- the Tanqua pan mosaics consist of vegetation units 7.2 on shales and alluvial deposits and 10 on brackish soils;

- the Windheuwel/Rooiheuwel mosaic consists of vegetation units $4.1,4.2$ on the rocky ridges and 7.3 on the brackish plains;

- the Naresie mosaic consists of elements of the Namaqualand Brokenveld as defined by Acocks (1953, 1988) and vegetation unit 6.4 .

The year in which the surveys were conducted (2004) was a poor rainfall year, and would have substantially reduced the annual and geophyte components of the vegetation. The resulting phytosociological tables thus poorly represent these two components. In normal or good rainfall years the contribution of the annuals and geophytes to the vegetation cover would be considerably higher.

\section{Description of plant associations (Tables 1a, 1b, 1c; Fig. 1)}

Two vegetation units, included in Table $1 \mathrm{a}$, have not been mapped as they fall outside the present study area and their linkages with the vegetation in the Van Rhynsdorp region still requires further study. These two units are related to what Acocks $(1953,1988)$ described as Succulent Karoo in the Van Rhynsdorp region, and are found along the Doorn River and its tributaries, the Biedouw Valley and the western extreme of the brackish system of the Hantam River in the vicinity of Van Rhynsdorp. The first unit is characterised by a strong presence of species group A, and a weak presence of species group B, while the second unit comprises species group B. At present it is not clear whether the unmapped units form part of association 4 or whether they have closer affinities to associations outside the study area.

\section{Pteronia glauca - Euphorbia decussata Escarpment Karoo}

This plant association is located along the Roggeveld Escarpment, the slopes of the Hantam Mountains, on the slopes alongside the Hantam River in the Agter-Hantam and to the west of the Stinkfontein, Lang and Boegoeberg Mountains, and has links to associations along the western part of the Doorn River and its tributaries (Fig. 1). Geologically, the Ecca Group dominates this association while tillite and dolerite intrusions are present at times. A variety of land types are found in this plant association, including $\mathrm{Fc}, \mathrm{Fb}, \mathrm{Ia}, \mathrm{Ib}, \mathrm{Da}$ and $\mathrm{Ag}$. The association generally occurs in lower-lying areas on level terrain, gentle or moderate to steep slopes. The percentage rock cover varies tremendously (0-99\%) and includes gravel, small stones, stones and boulders. Shrub cover is usually high, while grass and annual cover is limited.

Prominent species included in this plant association are Pteronia glauca (species group C, Table 1a), Euphorbia decussata (species group D), Pentzia incana and Ruschia cradockensis (species group N), as well as Tripteris sinuata, Drosanthemum (HR217) sp. and Galenia africana (species group V). Plant associations 4, 5 and 6 are closely related because they share the common species in species group N, yet associations 4 and 5 (Table 1a) differ from association 6 (Table $1 \mathrm{~b}$ ) since both associations 4 and 5 lack species group $U$.

\subsection{Montina caryophyllacea - Pteronia glauca Roggeveld Escarpment Karoo}

This subassociation characterises the vegetation of the Roggeveld Escarpment, i.e. the west-facing slopes of the Roggeveld Mountains (Fig. 1), and also forms part of the Houhoek, Kalkgat as well as Windheuwel/Rooiheuwel mosaics. Subassociation 4.1, excluding the various mosaic vegetation units, covers an area of 152057 ha $(9.2 \%$ of the total area in Fig. 1). The subassociation occurs at intermediate altitudes of 700 to $1100 \mathrm{~m}$ above sea level, on gentle to moderate, and sometimes steep, slopes. A high rock cover of generally more than $90 \%$, comprising small stones, stones and boulders, is found in this subassociation. The land type is predominantly Fc. The light brown to brown coloured loamy soils are derived from Ecca shales.

The vegetation is characterised by a high shrub cover (50-90\%) and grasses are usually absent. A very low cover of annuals can be found in certain areas. Subassociation 4.1 comprises species group $B$ and there is a strong presence of the diagnostic species group C (Table 1a). The vegetation is dominated by Pteronia glauca (species group C) that is constantly present and often has a very high canopy cover. Other prominent species present include Tylecodon wallichii and Montinia caryophyllacea (species group B)

\subsection{Galenia africana - Pteronia glauca Escarpment Karoo}

Plant subassociation 4.2 is located on the slopes of the Hantam Mountain, the undulating slopes of the escarpment in the Platberg and surrounding area southwest of Calvinia, and the slopes where the Roggeveld and Klein Roggeveld Mountains meet (Fig. 1). Subassociation 4.2, excluding the mosaic vegetation units, covers an area of 45047 ha $(2.7 \%$ of the total area in Fig. 1). It is also found in the mosaic between the Roggeveld and Koedoesberg Mountains in the vicinity of the farms Windheuwel and Rooiheuwel. Elements of this subassociation are found on the ridges between the dolerite derived soils in the 


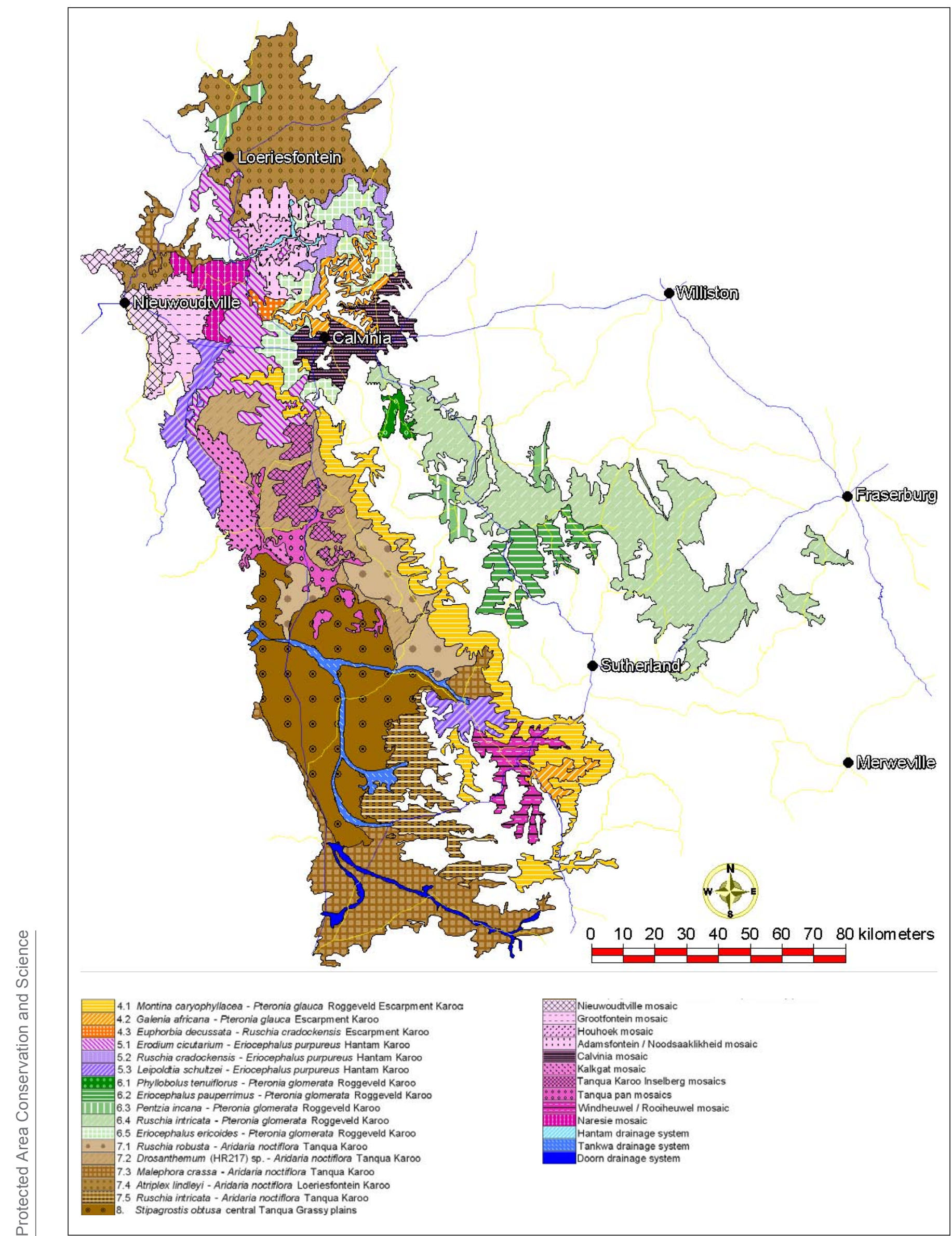

FIGURE 1

Vegetation map of the Succulent Karoo Biome related vegetation of the Hantam-Tanqua-Roggeveld subregion 
Grootfontein mosaic in the Hantam along the R27 national road, east of Nieuwoudtville. Land types are numerous, and include $\mathrm{Fb}$, Ia, Ib and $\mathrm{Da}$, at altitudes ranging from 700 to $1200 \mathrm{~m}$ above sea level. Ecca shales and dolerite intrusions predominate in this vegetation unit on gently sloping terrain. A low rock cover $(<10 \%)$ or a high rock cover $(>80 \%)$, consisting of gravel, small stones, stones and boulders covers the light brown or brown loamy soils.

Shrub cover in this subassociation is high $(>70 \%)$, while the grass and annual components are not well represented. Pteronia glauca (species group C) is diagnostic of this subassociation (Table 1a). Other species present include Pentzia incana, Eriocephalus ericoides (species group N) and Tripteris sinuata, Drosanthemum (HR217) sp. and Galenia africana (species group V).

\subsection{Euphorbia decussata - Ruschia cradockensis Escarpment Karoo}

This small subassociation occurs at lower altitudes of 400 to $1200 \mathrm{~m}$ above sea level, to the west of the Hantam Mountain and, excluding the mosaic vegetation units, covers an area of 5196 ha $(0.3 \%$ of the total area in Fig. 1). Elements of this subassociation can also be found closer to Nieuwoudtville in the Grootfontein mosaic as well as in the Agter-Hantam in the Houhoek mosaic where it covers the lower slopes. The Ecca Group dominates in this subassociation, while tillite and dolerite intrusions are present in the mosaics. Land types include $\mathrm{Fb}, \mathrm{Fc}, \mathrm{Da}, \mathrm{Ag}$ and $\mathrm{Ib}$, resulting in the mosaic vegetation. The level, gently or moderately sloping ridges are usually covered with either very little rock $(0-5 \%)$ or much rock (60-99\%). Small stones, stones and boulders are present in the light brown to brown loamy soils.

Shrub cover is high (45-95\%), whereas the grass and annual components are generally weakly developed. The dominant species are Euphorbia decussata (species group D, Table 1a) and Ruschia cradockensis (species group N), and both these species generally have a high cover. Other species present include Tetragonia fruticosa (species group N), Tripteris sinuata, Drosanthemum (HR217) sp. and Galenia africana (species group V).

\section{Eriocephalus purpureus Hantam Karoo}

Association 5 occurs in the vicinity of the farm Matjiesfontein, close to Calvinia, northwards to Loeriesfontein and southwards to the farm Klipbak. It also occurs as part of the Grootfontein mosaic, westwards along the R27 national road to the Nieuwoudtville mosaic, as described by Van der Merwe et al. (2008). Additionally, it is found in the Agter-Hantam (Adamsfontein/Noodsaaklikheid mosaic) and on small inselbergs into the Tanqua Karoo, such as the Nuwewater se berg, Elandsberg, Eselberg, Leeuberg, Potkleiberg and Sterretjieberg (Tanqua Karoo Inselbergs mosaic) (Fig. 1). The altitude is lower than $1000 \mathrm{~m}$ and an array of land types occur, including Dc, Fc, Da and Ag. The level to gently sloping ridges usually have a low rock cover. The brown, red brown or light brown loams and clays are derived from Ecca shales and Dwyka tillite, as well as dolerite intrusions that scatter the landscape.

The shrub cover varies considerably $(0-80 \%)$ and grasses are generally absent. The cover of the annual component ranges from very little to $95 \%$. It is assumed that the annual component contributes substantially to the total aboveground biomass in good rainfall years since the area is renowned for its annual and geophyte spring displays. Eriocephalus purpureus (species group I) and Leipoldtia schultzei (species group J) characterise the vegetation of this association (Table 1a). Other prominent species include Pentzia incana, Ruschia cradockensis, Asparagus capensis, Tetragonia fruticosa and Eriocephalus microphyllus from species group N, as well as Aridaria noctiflora and Galenia africana from species group V. Plant association 5 is closely related to both associations 4 (Table 1a) and 6 (Table 1b) due to the common species in species group $\mathrm{N}$. This association is subdivided into three subassociations.

\subsection{Erodium cicutarium - Eriocephalus purpureus Hantam Karoo}

The two variations of this subassociation (Table 1a) are mainly due to the presence or absence of annuals and/or geophytes in species groups $E$ and $F$, which could be as a result of the drought year in which the surveys were conducted. These life forms are rainfall dependent and thus by conducting the same surveys in a good rainfall year it might not be possible to distinguish between the two variations.

This subassociation occurs in the vicinity of the farm Matjiesfontein, close to Calvinia, southwards to the farm Klipbak and northwards to Loeriesfontein (Fig. 1). Subassociation 5.1, excluding the mosaic vegetation units, covers an area of 92682 ha (5.6\% of the total area in Fig. 1). It also occurs as part of the Grootfontein mosaic, as well as westwards to the Nieuwoudtville mosaic where it occurs in combination with variants 2.1.1, 2.1.4 and subassociation 2.2 (Van der Merwe et al. 2008). The subassociation is found on the Ecca Group where dolerite intrusions occur in the landscape, on level to gently sloping areas, at an altitude from 700 to $1000 \mathrm{~m}$ above sea level on Land Types Fb, Ea, Dc or Da. Soils are clays or loams of red brown or dark brown colour, with little or no rocks.

Shrub cover is highly variable $(<5-75 \%)$ and the contribution of the grass component is very small. Annual cover varies from $<1 \%$ to $95 \%$, indicating its high variability. Subassociation 5.1 differs from 5.2 by the presence of species groups E, F and G, which occur only in subassociation 5.1 (Table 1a). Common species include Erodium cicutarium (species group G), Ehrharta calycina (species group H), Eriocephalus purpureus and Tetragonia microptera (species group I), Pentzia incana, Ruschia cradockensis and Asparagus capensis (species group N).

\subsection{Ruschia cradockensis - Eriocephalus purpureus Hantam Karoo}

Subassociation 5.2 occurs as a clearly defined vegetation unit as well as in various mosaic vegetation units. As a clearly defined unit it occurs in the Agter-Hantam near Klipwerf (Fig. 1) and, excluding the mosaic vegetation units, covers an area of 22353 ha (1.3\% of the total area in Fig. 1). Here the subassociation is found on the Ecca Group while dolerite intrusions are scattered throughout the landscape. As part of a mosaic, it occurs north and south of the Hantam River in the Adamsfontein/Noodsaaklikheid mosaic. It also occurs on dolerites on the inselbergs south of Calvinia into the Tanqua Karoo (Tanqua Karoo Inselbergs mosaic). These inselbergs include the Nuwewater se berg, Elandsberg, Eselberg, Leeuberg, Potkleiberg and Sterretjieberg. Additionally, subassociation 5.2 occurs in the Grootfontein mosaic vegetation unit on the dolerite derived soils. This subassociation generally occurs on Land Types $\mathrm{Fb}$ and $\mathrm{Fc}$ at altitudes from 700 to $1000 \mathrm{~m}$ above sea level. The rock cover varies considerably from zero to $90 \%$ and includes small stones, stones and boulders. The underlying red brown or brown soils are clays and loams, primarily derived from the dolerites and the Ecca shales.

Shrub cover ranges from 40 to $90 \%$, while the grass and annual components are usually absent or $<5 \%$. Ehrharta calycina (species group H), Eriocephalus purpureus (species group I), Pentzia incana and Ruschia cradockensis (species group N), as well as Aridaria noctiflora (species group V) are prominent in this subassociation (Table 1a).

Subassociation 5.2 is closely related to subassociation 5.1 as they both include species groups $\mathrm{H}, \mathrm{I}, \mathrm{J}, \mathrm{N}$ and V, but it differs from the latter by the absence of species groups E, F and G. Subassociation 5.2 is also closely related to subassociation 5.3, from which it only differs by the absence of species group $\mathrm{H}$ in the latter. 


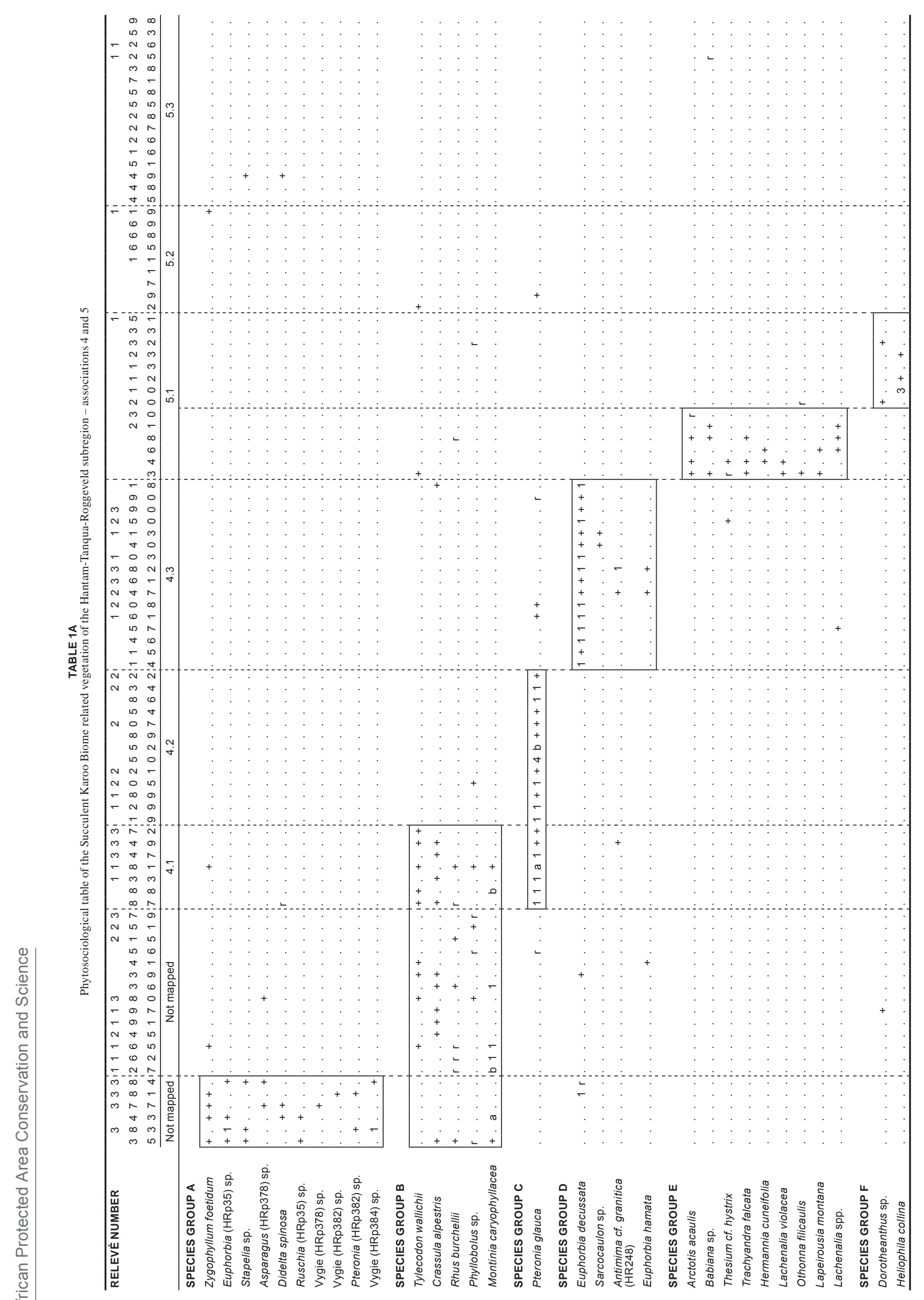




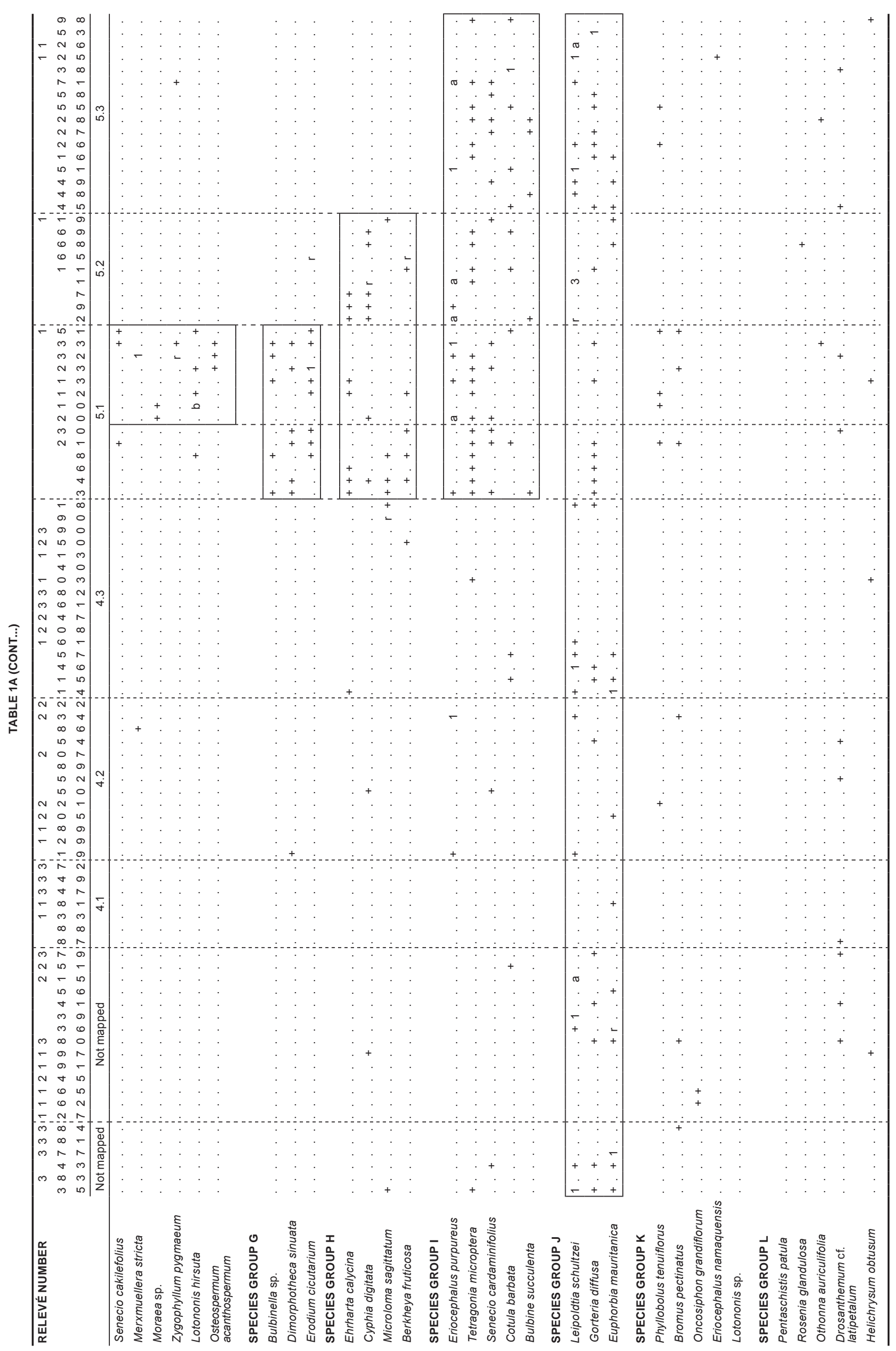




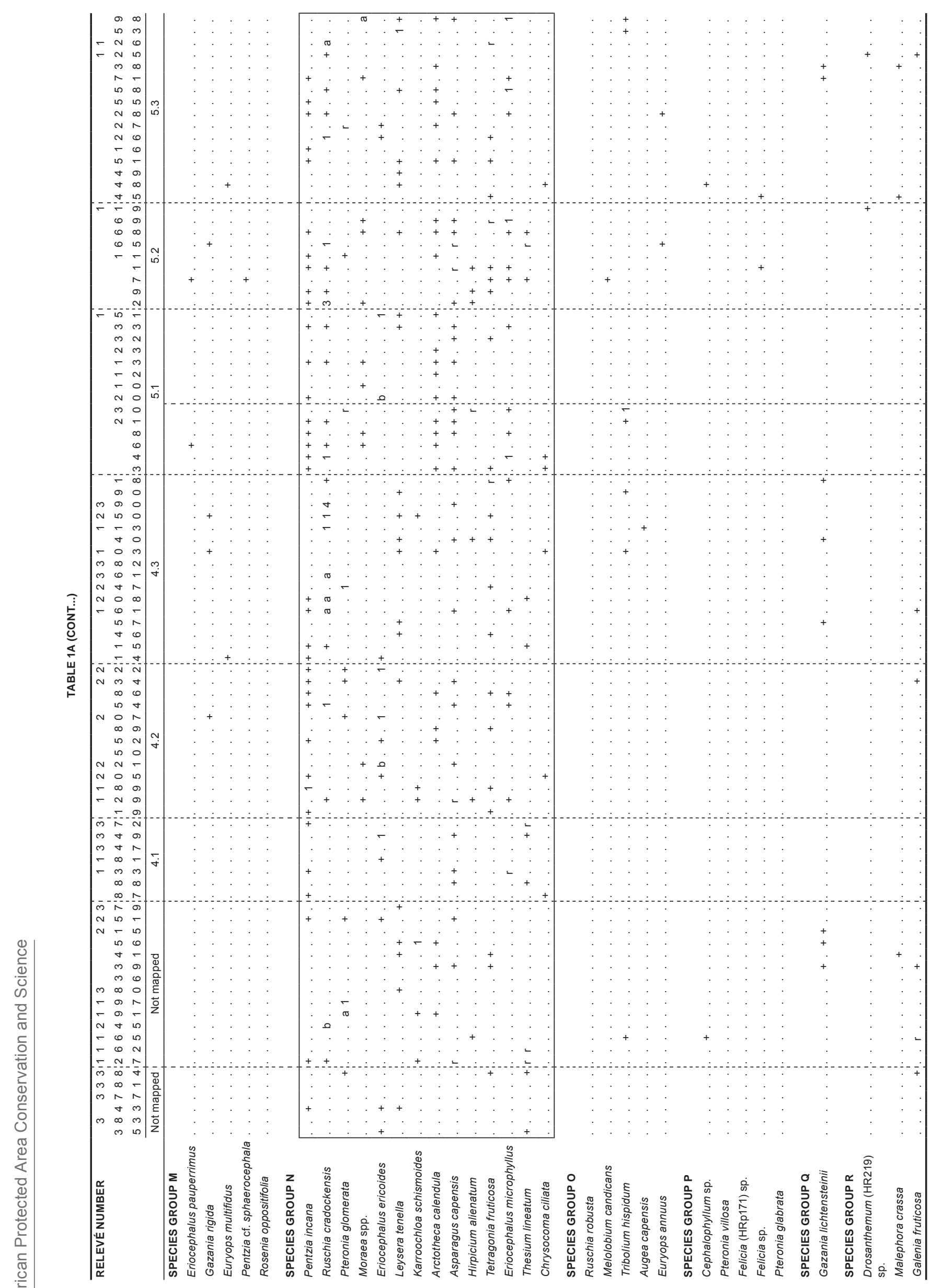




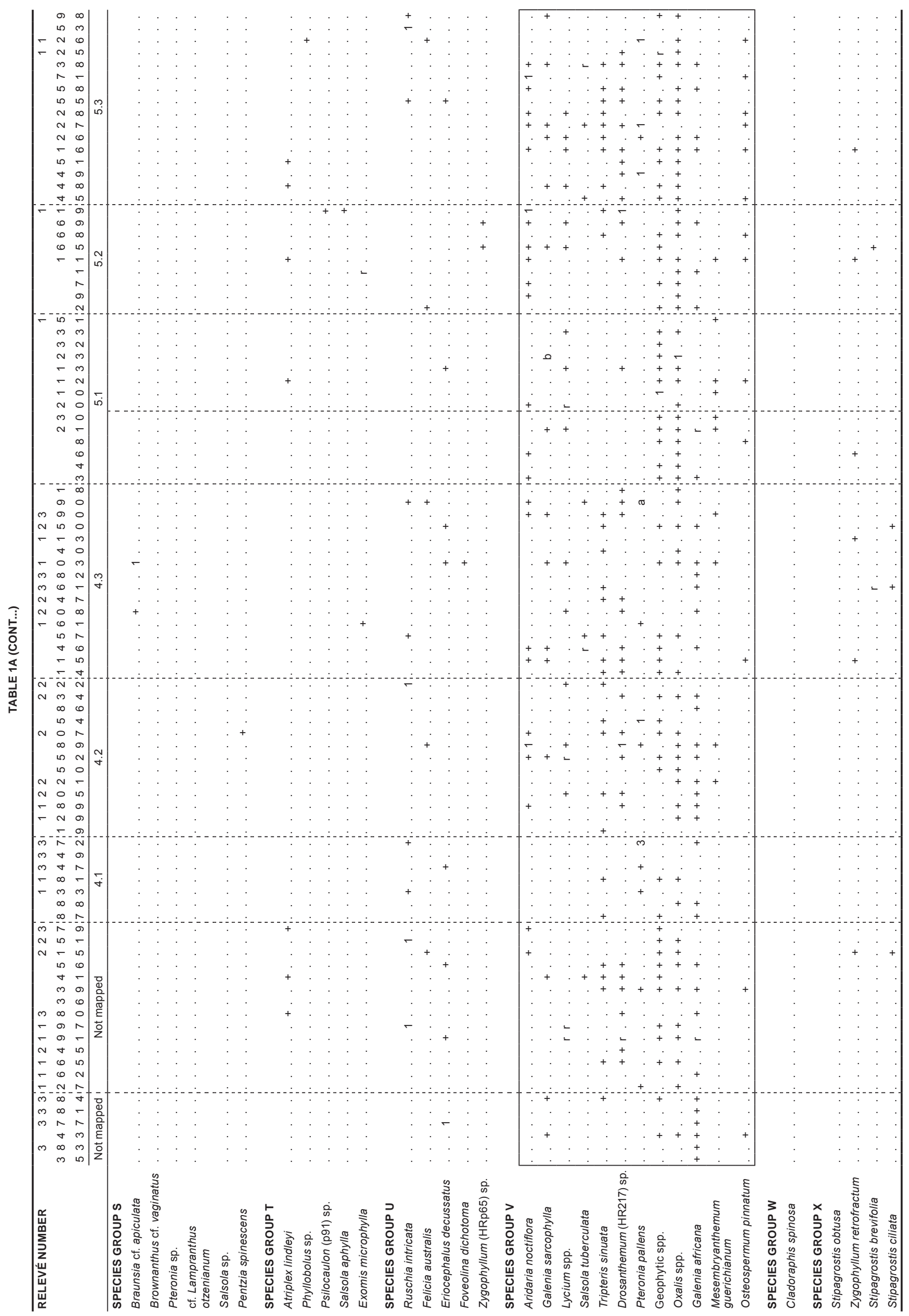




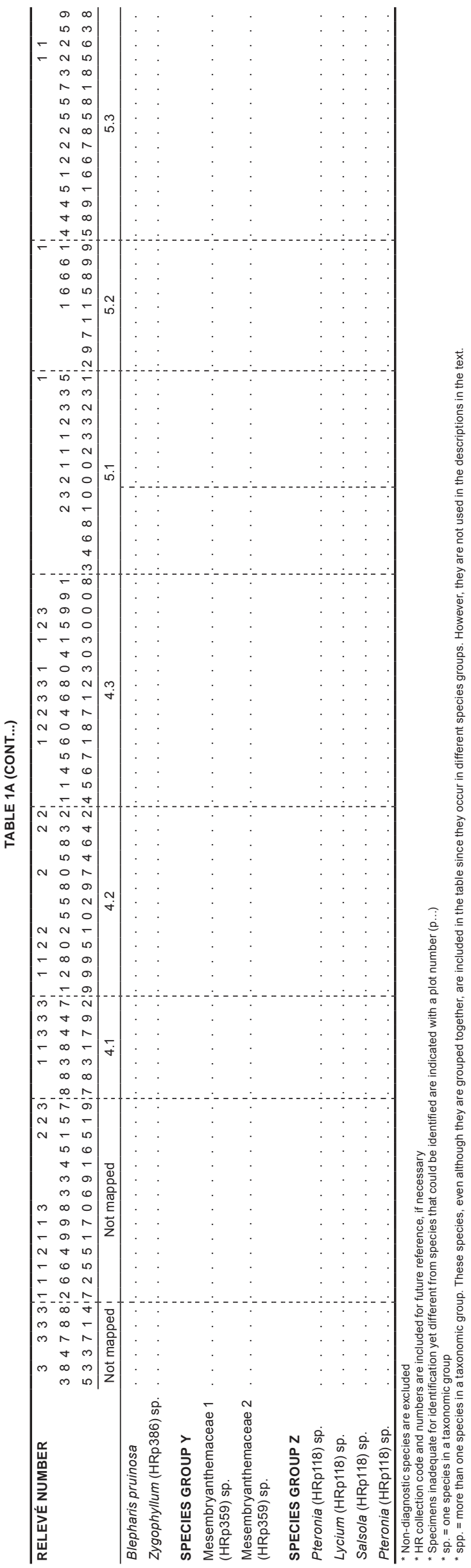

5.3 Leipoldtia schultzei - Eriocephalus purpureus Hantam Karoo

This subassociation is located around the farms Soetwater and Leeuriet southwest to Mensieskraal and stretches southeastwards to approximately the farm Soutpan (Fig. 1). It covers an area of 58214 ha (3.5\% of the total area in Fig. 1). Subassociation 5.3 occurs on Dwyka tillites and Ecca shales at an altitude ranging from 300 to $1000 \mathrm{~m}$, and the dominant land types are $\mathrm{Da}$ and Fc. The ridges of this subassociation are generally level, occasionally gentle, with a low rock cover. The loamy soils are red brown or light brown in colour.

Shrub cover in this subassociation varies from 45 to $80 \%$. The grass component is absent while the annual component varies greatly, from $<1 \%$ to $60 \%$. Subassociation 5.3 shares species groups I and J with subassociations 5.1 and 5.2 but lacks its own defining group (Table 1a). The dominant species are Leipoldtia schultzei and Gorteria diffusa (species group J), while other species describing this subassociation include Pentzia incana, Ruschia cradockensis and Eriocephalus microphyllus (species group N), as well as Aridaria noctiflora, Tripteris sinuata, Drosanthemum (HR217) sp. and occasionally a high cover of Pteronia pallens (species group V).

\section{Pteronia glomerata Roggeveld Karoo}

This association is predominantly found along the eastern boundary of the study area (Fig. 1) and has been termed Roggeveld Karoo. The Ecca Group, characterised by shales, and the Beaufort Group, characterised by mudstones, meet in this transitional area. Additionally, this area is the transition between the winter rainfall region to the west and the summer rainfall region to the east. In general, this association occurs at an altitude greater than $1000 \mathrm{~m}$ above sea level and predominantly on Land Types Fc or Da. The level to gently sloping ridges, plains and valleys commonly have light brown or brown loamy soils.

A high shrub cover (usually $>60 \%$ ) is found, whereas the grass and annual components are absent or $<5 \%$. Association 6 (Table $1 \mathrm{~b}$ ) is related to associations 4 and 5 (Table 1a) through common species such as Pentzia incana, Ruschia cradockensis and Pteronia glomerata (species group N), but also related to association 7 (Table 1c) through common species such as Ruschia intricata and Eriocephalus decussatus (species group U).

\subsection{Phyllobolus tenuiflorus - Pteronia glomerata Roggeveld Karoo}

Located in the vicinity of the farms Rooiwal and Weltevrede on dolerite soils, southeast of Calvinia (Fig. 1), subassociation 6.1 is found predominantly on Land Types Fc and Ag, and covers an area of 9172 ha $(0.6 \%$ of the total area in Fig. 1). It is generally found on level terrain to gently sloping ridges and plains at an altitude varying from 1000 to $1300 \mathrm{~m}$ above sea level. Soils are loamy and usually brown, with a rock cover that ranges from zero to $80 \%$, comprising small stones and stones.

Shrub cover in this subassociation varies from 5 to $90 \%$. The grass component is generally absent except in isolated cases where it can be as high as 25 to $40 \%$. The annual component varies considerably from $<1 \%$ to $60 \%$. Subassociation 6.1 comprises species groups $\mathrm{K}, \mathrm{N}, \mathrm{U}$ and $\mathrm{V}$ but lacks species groups $\mathrm{L}$ and $\mathrm{M}$, which are present in subassociations 6.2, 6.3 and 6.4 (Table 1b). Annual species include Phyllobolus tenuiflorus (species group K), Felicia australis and Foveolina dichotoma (species group U), and Galenia sarcophylla (species group V), while perennial species include Pentzia incana, Ruschia cradockensis and Pteronia glomerata (species group N) (Table 1b).

\subsection{Eriocephalus pauperrimus - Pteronia glomerata Roggeveld Karoo}

This subassociation is located within the Basterberg Mountains (Fig. 1) and covers an area of 50790 ha $(3.1 \%$ of the total area 
in Fig. 1). It is predominantly found on Land Types Da and Fc at an altitude of 1100 to $1400 \mathrm{~m}$. These level to gently sloping mudstone ridges of the Beaufort Group are covered with brown or light brown coloured loamy soils with a rock cover varying from zero to $95 \%$ stone.

The shrub cover is high while the grasses and annuals make little contribution to the overall plant cover. Conspicuous species in this subassociation include Phyllobolus tenuiflorus (species group K) and Eriocephalus pauperrimus (species group M) (Table 1b). Other common species are Pentzia incana, Ruschia cradockensis, Pteronia glomerata, Karroochloa schismoides (species group N), Eriocephalus decussatus (species group U) and Tripteris sinuata (species group V).

\subsection{Pentzia incana - Pteronia glomerata Roggeveld Karoo}

Subassociation 6.3 is located in the vicinity of Elandsoog se berg, around the farm De Puts, southwest of the Droëberg Mountains and northeast of Loeriesfontein (Fig. 1), and covers an area of 31594 ha $(1.9 \%$ of the total area in Fig. 1). This subassociation is found on mudstones of the Beaufort Group and shales of the Ecca Group, and predominantly on Land Type Da. The altitude ranges from 1000 to $1200 \mathrm{~m}$ and the subassociation is found on relatively level areas of ridges, plains and valleys. Generally, the light brown loamy soils have little rock cover but when rock occurs it is in the form of stones or boulders.

The shrubby component in this subassociation is well developed but grasses and annuals are usually absent or contribute very little to the overall cover. Eriocephalus pauperrimus (species group $\mathrm{M})$ has a high cover in this subassociation, which is closely related to subassociations 6.2 and 6.4 through the presence of species group $\mathrm{M}$ (Table 1b). Other species present include Pentzia incana and Eriocephalus ericoides (species group N) and Ruschia intricata (species group U), as well as various Lycium species (species group V).

\subsection{Ruschia intricata - Pteronia glomerata Roggeveld Karoo}

Subassociation 6.4 is located north to south along the eastern boundary of the study area, predominantly on mudstones of the Beaufort Group (Fig. 1) and, excluding the mosaic vegetation units, covers an area of 265394 ha (16\% of the total area in Fig. 1). It forms the transition with the Arid Karoo and False Succulent Karoo, as described by Acocks (1953, 1988). Elements of this subassociation are also found in the transition with the Namaqualand Broken Veld (Acocks 1953, 1988), west of the Hantam Mountain, in the Naresie mosaic vegetation unit, predominantly on Dwyka tillite. This subassociation is found on Land Types Fc and Da at an altitude ranging from 800 to $1400 \mathrm{~m}$ above sea level. The level terrain and gentle slopes are usually covered in light brown or brown coloured soils with either a low rock cover $(0-15 \%)$ or a high rock cover $(80-95 \%)$.

Shrub cover usually ranges from 50 to $90 \%$, while grass and annual cover is usually absent or $<5 \%$. Common species include Rosenia glandulosa (species group L), Eriocephalus pauperrimus (species group M), Pentzia incana, Ruschia cradockensis, Pteronia glomerata, Eriocephalus ericoides (species group N), Ruschia intricata, Eriocephalus decussatus (species group U), Aridaria noctiflora and Tripteris sinuata (species group V) (Table 1b).

\subsection{Eriocephalus ericoides - Pteronia glomerata Roggeveld Karoo}

This subassociation, located on Land Type $\mathrm{Fc}_{\mathrm{c}}$ is found northeast and southwest of the Hantam Mountain (Fig. 1) and, excluding the mosaic vegetation units, covers an area of 69356 ha $(4.2 \%$ of the total area in Fig. 1). It is also located in a mosaic vegetation unit around the town of Calvinia (Calvinia mosaic) and in the Adamsfontein/Noodsaaklikheid mosaic. Geologically, the Ecca Group dominates these areas, with dolerite intrusions interrupting the shales. The subassociation occurs at altitudes ranging from 900 to $1200 \mathrm{~m}$ above sea level on level to gently sloping ridges, with generally a higher rock cover than in subassociations $6.1,6.2$ and 6.3 .

The shrub layer covers 40 to $80 \%$ of the light brown and brown loamy soils, while the grass and annual component is either absent or covers $<5 \%$. Subassociation 6.5 differs from the previous subassociations because it lacks species groups K, L and $\mathrm{M}$ (Table 1b). Dominant species in this subassociation are Pentzia incana, Pteronia glomerata, Eriocephalus ericoides (species group N), Ruschia intricata (species group U), Aridaria noctiflora, Tripteris sinuata and Galenia africana (species group V). These species are all common to the entire association 6.

\section{Aridaria noctiflora Tanqua Karoo}

Association 7 is located primarily in the Tanqua Karoo Basin and the adjacent foothills of the Koedoesberg Mountains. Large areas east and northeast of Loeriesfontein, as well as on the western extreme of the Hantam River, a brackish system, are also included in this association, as well as the vegetation mosaic located around the town of Calvinia (Fig. 1). Geologically, shale of the Ecca Group and tillite of the Dwyka Group dominate association 7, while alluvial deposits are present at times. Limited intrusions of dolerite also occur. This association is found predominantly on Land Types Ia and Fc at an altitude ranging from 200 to $1100 \mathrm{~m}$. The level to gently sloping ridges and plains occur on brown and light brown soils, with generally a low rock cover.

Shrub cover is intermediate (ca. $40 \%$ ), while the grass and annual components are absent or poorly developed. The annual component is expected to be much higher in normal and good rainfall years. Association 7 (Table 1c) differs from associations 4 to 6 (Table 1a, 1b) as it lacks species group $\mathrm{N}$ but shares species groups $\mathrm{U}$ and $\mathrm{V}$ with association 6 (Table $1 \mathrm{~b}$ ). Associations 4 to 7 (Table 1a, 1b, 1c) are related through the shared presence of species groups $\mathrm{V}$, and have no species groups in common with associations 8, 9 and 10 (Table 1c). Common species in association 7 are Ruschia intricata (species group U), Aridaria noctiflora, Salsola tuberculata, Tripteris sinuata and Drosanthemum (HR217) sp. (species group V). This association is subdivided into five subassociations (Table 1c).

\subsection{Ruschia robusta - Aridaria noctiflora Tanqua Karoo}

Subassociation 7.1 is located at the eastern edge of the Tanqua Basin at the foot of the Roggeveld Escarpment and in the vicinity of the farm Twee Damme, and covers an area of 79395 ha $(4.8 \%$ of the total area in Fig. 1). This low-lying (300-800 m above sea level) subassociation is found on the Ecca Group on gently sloping ridges and plains with brown coloured loamy soils of Land Types Ia and Fc. Rock cover varies considerably, from no rocks to 50 to $99 \%$ consisting of small stones (> 10-50 $\mathrm{mm}$ )

Shrub cover is generally low, but can be as high as $75 \%$. Grass cover is low or absent, while annual cover ranges from very low (the norm) to isolated dense patches (50-80\%). This subassociation is characterised by perennials such as Ruschia robusta, Augea capensis and the annual Euryops annuus (species group O) (Table 1c). Other perennial species are Aridaria noctiflora, Drosanthemum (HR217) sp. and Pteronia pallens (species group V), and annual species include Gazania lichtensteinii (species group Q) and Felicia australis (species group U).

\subsection{Drosanthemum (HR217) sp. - Aridaria noctiflora Tanqua} Karoo

Subassociation 7.2 is located on the alluviums in the vicinity of the farms Weltevreden and Platfontein, southwest of Calvinia (Fig. 1) and, excluding the mosaic vegetation units, covers an 


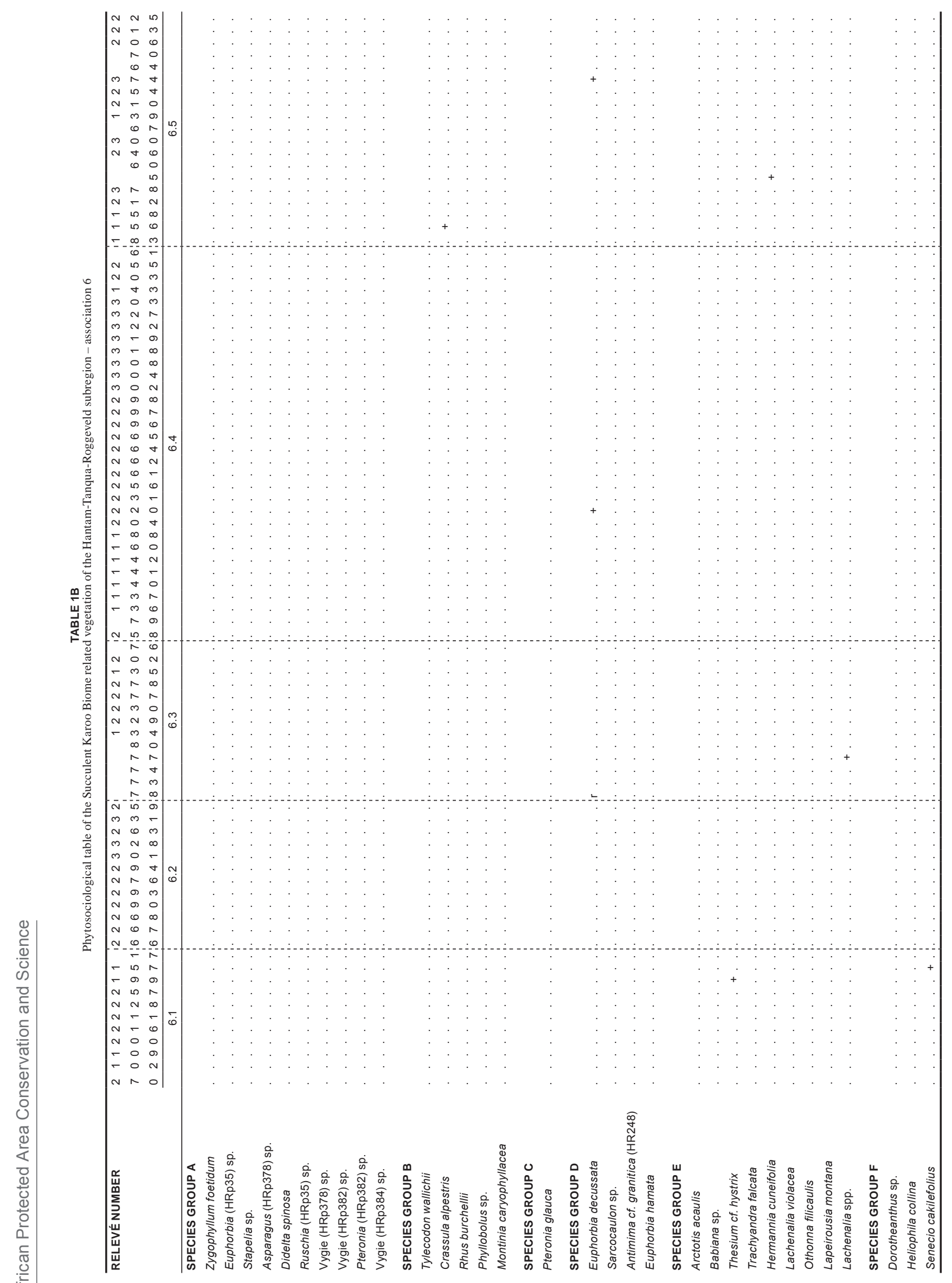




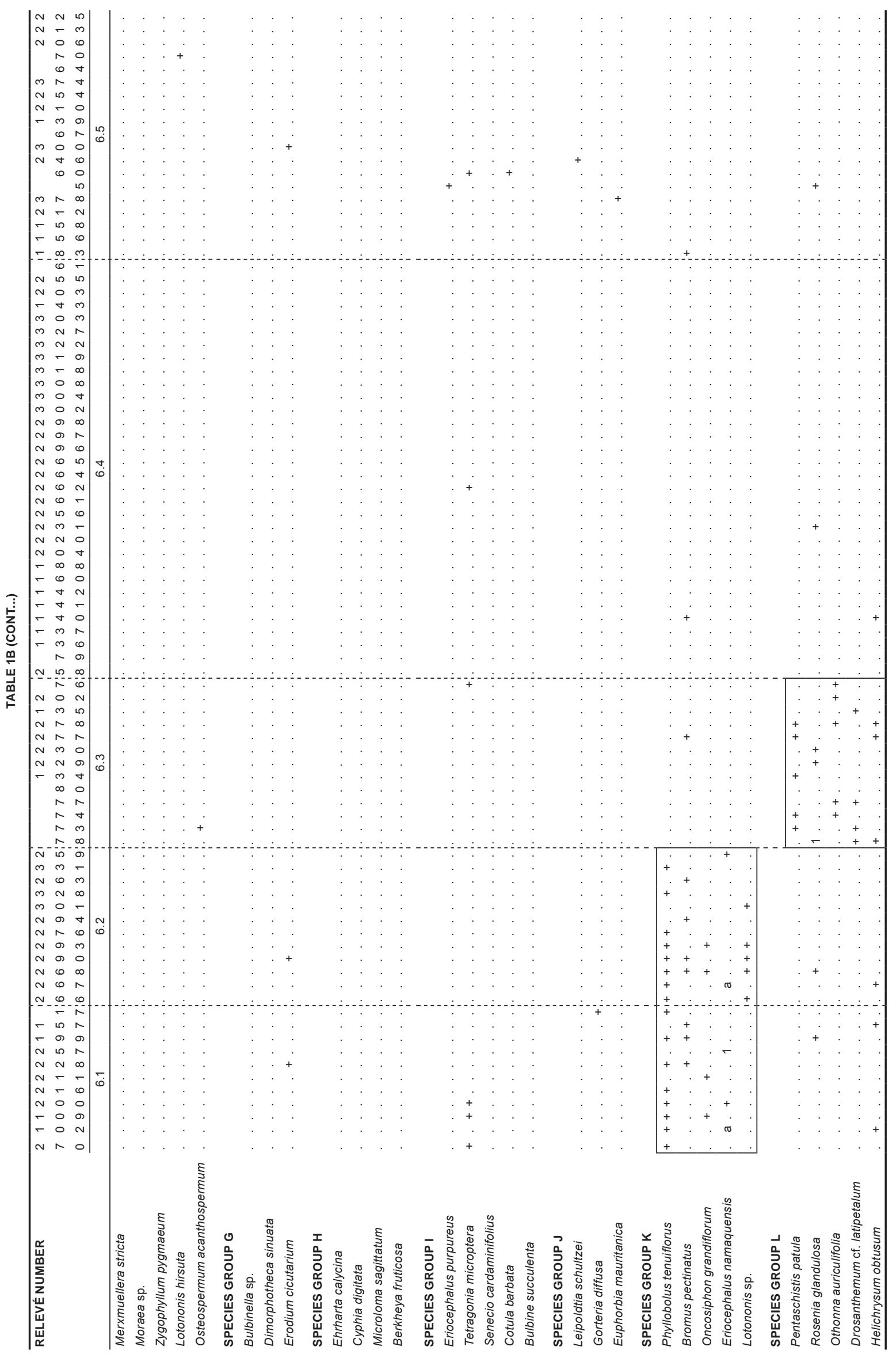




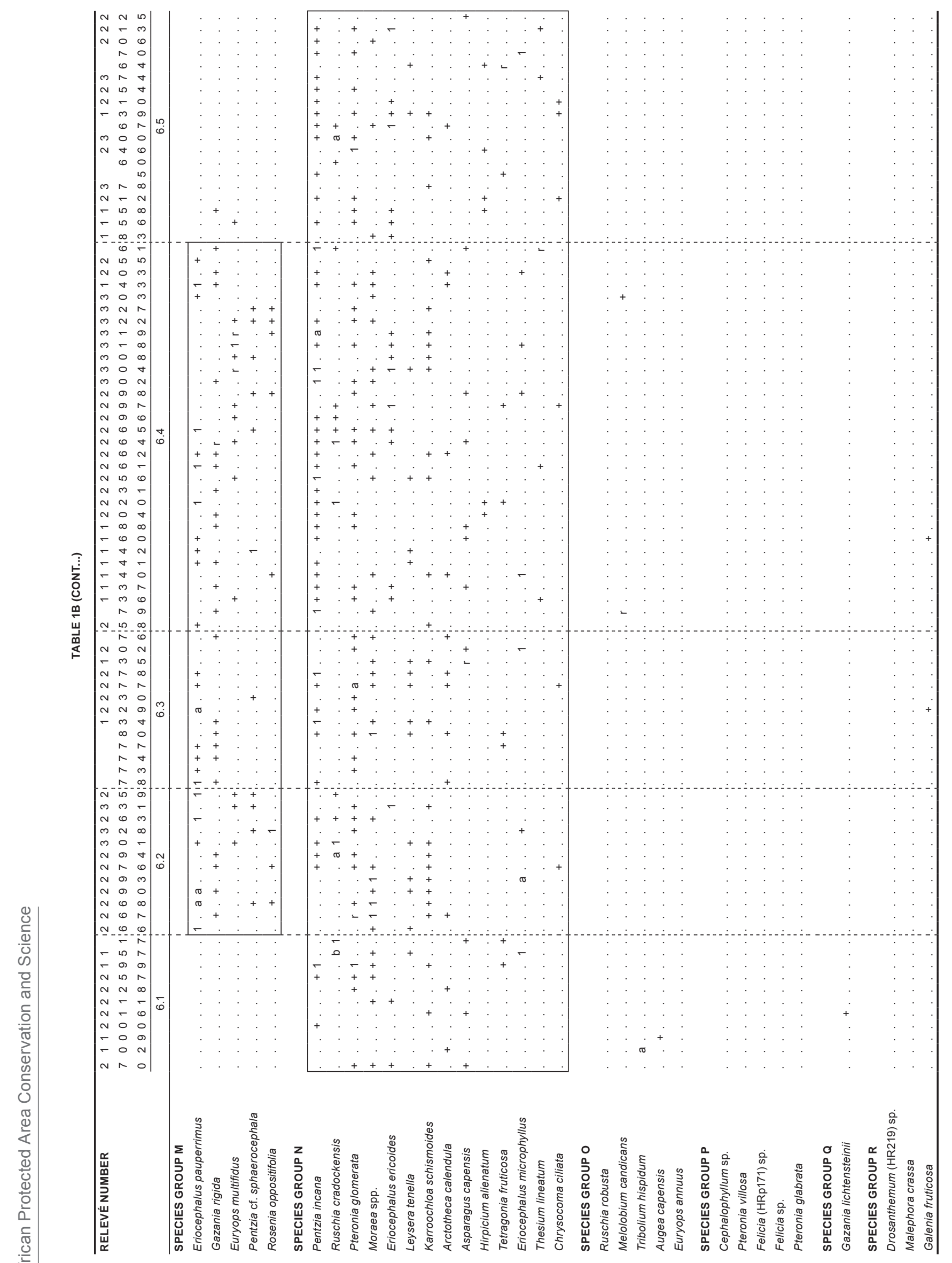




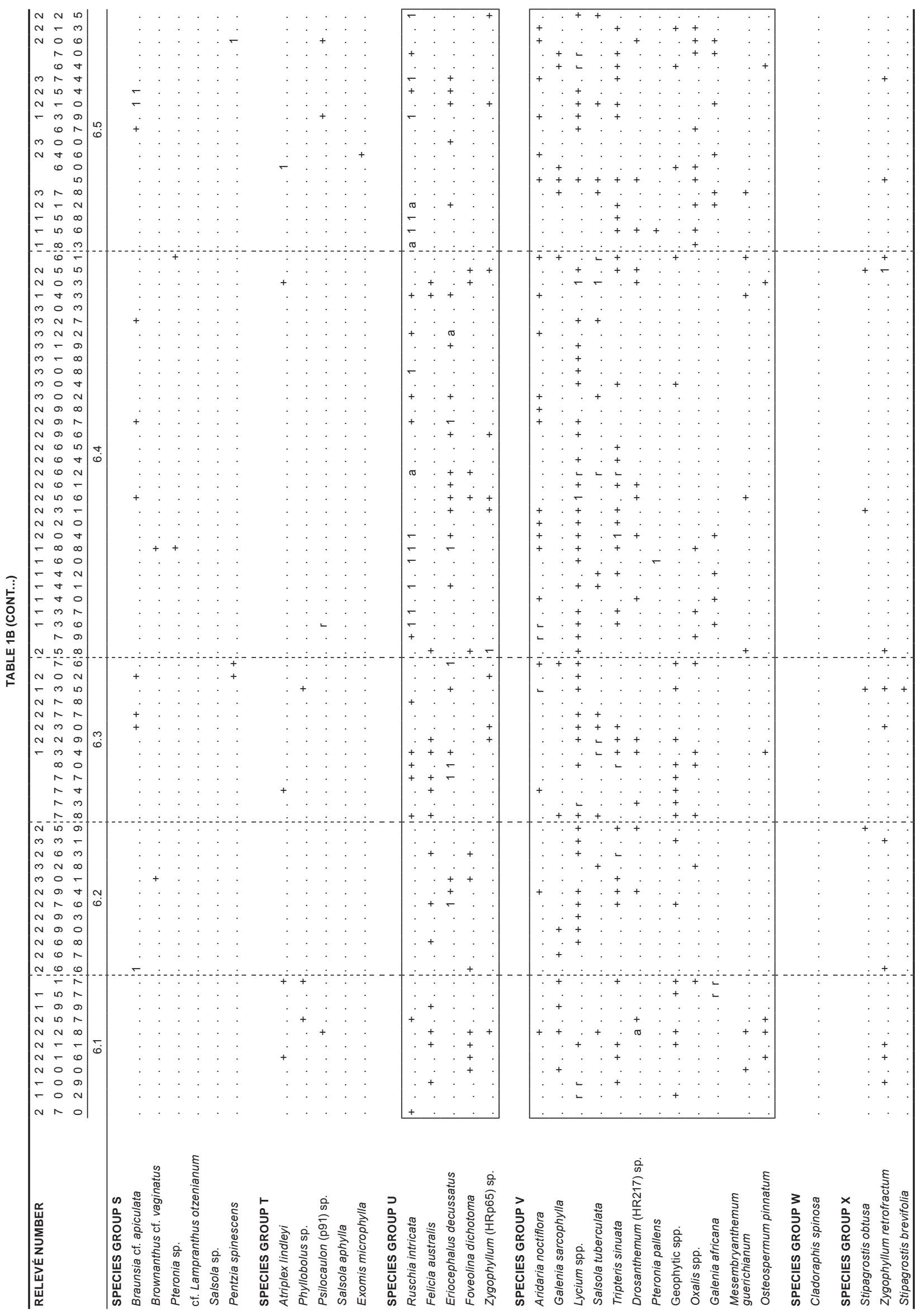




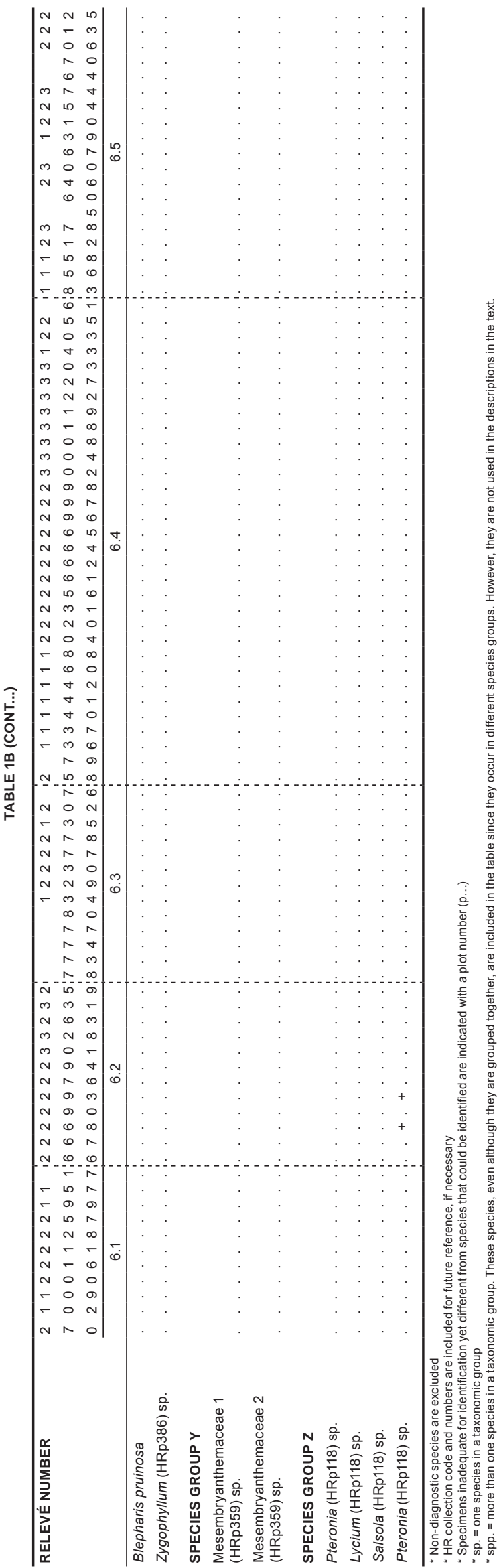

area of 103665 ha (6.2\% of the total area in Fig. 1). It is also found near Kalkgat in the north of the Tanqua Basin (Kalkgat mosaic) and in the pan system in the Tanqua Basin (Tanqua pan mosaics). It occurs predominantly on Land Types Ia and Fc. Geologically, alluvial deposits dominate, while shales of the Ecca Group are present at times. Limited intrusions of dolerite also occur. This low-lying (400-800 m above sea level) subassociation is found on level to gently sloping ridges and plains with no rock cover or a 50 to $98 \%$ rock cover comprising small stones. The sands are brown, light brown or red brown in colour.

The shrub cover is intermediate to high (30-80\%), the grassy component is absent, and annual cover is very low. The subassociation is characterised by a weak species group $\mathrm{P}$ with species such as Cephalophyllum sp., Pteronia villosa and Pteronia glabrata (Table 1c). Other common species include Malephora crassa (species group R), Ruschia intricata (species group U) as well as Aridaria noctiflora, Salsola tuberculata, Tripteris sinuata and Pteronia pallens (species group V). Subassociations 7.1 and 7.2 share Gazania lichtensteinii of species group Q.

\subsection{Malephora crassa - Aridaria noctiflora Tanqua Karoo}

This subassociation is found predominantly at the southern extreme of the Tanqua Basin, i.e. Ceres Karoo, as well as on the western extreme of the Hantam River where the river system is brackish (Fig. 1). Subassociation 7.3, excluding the mosaic vegetation units, covers an area of 176425 ha $(10.6 \%$ of the total area in Fig. 1). It also occurs in the Kalkgat mosaic southwest of Calvinia and in the Windheuwel/Rooiheuwel mosaic between the Roggeveld and Koedoesberg Mountains. Shales of the Ecca Group and tillite of the Dwyka Group are found in these areas. Land Types $\mathrm{Da}$, Ia and Fc dominate the area that ranges in altitude from 200 to $1000 \mathrm{~m}$ above sea level. These generally level ridges and plains have a low rock cover on light brown loamy soils.

Shrub cover averages 30 to $40 \%$, while the cover of grasses and annuals is absent or very low. There is no diagnostic species group defining subassociation 7.3 (Table 1c). Prominent species include Malephora crassa (species group R), Atriplex lindleyi (species group T), Ruschia intricata (species group U), Aridaria noctiflora, Salsola tuberculata, Drosanthemum (HR217) sp. and Pteroniapallens (species group V). Theabsence of species groups $\mathrm{O}$, $P$ and $Q$ distinguishes this subassociation from subassociations 7.1 and 7.2, but the presence of species group R shows affinity with them. A relationship with subassociation 7.4 is indicated by the shared presence of species group $\mathrm{T}$ (Table 1c).

\subsection{Atriplex lindleyi - Aridaria noctiflora Loeriesfontein Karoo}

Subassociation 7.4 is located around the town of Loeriesfontein and east thereof (Fig. 1) and, excluding the mosaic vegetation unit, covers an area of 184612 ha (11.1\% of the total area in Fig. 1). In the Calvinia mosaic subassociation 7.4 (Table 1c) is found in combination with subassociation 6.5 (Table 1b). These areas are closely associated with what Acocks $(1953,1988)$ termed False Succulent Karoo. The vegetation has a desert character and is sparsely populated with mesembs (vygies) and relics of the Arid Karoo. The degradation of the vegetation has been ascribed to the excessive grazing pressure and, consequently, the species that are of value for grazing are precisely the ones that no longer appear in it (Acocks 1953, 1988). This subassociation occurs on the shales of the Ecca group and a network of Karoo dolerites, predominantly on Land Types Ia, Fc and Da, at an altitude ranging from 400 to $1000 \mathrm{~m}$. These usually level ridges generally have a low rock cover on the brown to light brown coloured loamy soils.

An intermediate shrub cover (40-60\%), and grass and annual components that are absent or very low, describe this subassociation. Species group S with species such as Braunsia cf. apiculata and Brownanthus cf. vaginatus characterise this subassociation (Table 1c). Atriplex lindleyi (species group T), 
Ruschia intricata (species group U), as well as Aridaria noctiflora, Salsola tuberculata and Tripteris sinuata (species group V) are also abundant.

\subsection{Ruschia intricata - Aridaria noctiflora Tanqua Karoo}

This subassociation is located at the foothills of the Koedoesberg Mountains (Fig. 1) and, excluding the mosaic vegetation unit, covers an area of 73290 ha $(4.4 \%$ of the total area in Fig. 1). It is also found in the Tanqua Karoo Inselberg mosaic south of Calvinia. These inselbergs include the Nuwewater se berg, Elandsberg, Eselberg, Leeuberg, Potkleiberg and Sterretjieberg. The subassociation occurs predominantly on the Skoorsteenberg Formation of the Ecca Group in Land Types Fc and Ia. In the mosaics it co-occurs with subassociation 5.2 (Table 1a), which occupies the dolerites of these inselbergs. The level to occasionally gently sloping ridges on light brown or brown coloured loams have either a low rock cover of $<5 \%$ or a high rock cover of 70 to $90 \%$.

An intermediate (40-45\%) shrub cover is present in this subassociation and the grass and annual components are usually absent. There is no diagnostic species group defining this subassociation and species groups $\mathrm{U}$ and $\mathrm{V}$ are the only links with the other subassociations in association 7 (Table 1c). Ruschia intricata (species group U) and Aridaria noctiflora (species group V) dominate the subassociation.

\section{Stipagrostis obtusa Central Tanqua Grassy Plains}

Association 8 is located in the central Tanqua Basin (Fig. 1) and covers an area of 239781 ha (14.5\% of the total area in Fig. 1). It occurs from 200 to $1000 \mathrm{~m}$ above sea level, predominantly on Land Type Fc. Tillite of the Dwyka Group and mudrock and shales of the Ecca Group comprise the geology of this area. The sandy plains and ridges generally have no rock cover or have a high rock cover in localised patches, with a 60 to $99 \%$ cover of gravel, small stones and/or stones. The sandy soils vary in colour from light brown to brown to red brown.

Shrub cover is less than $20 \%$, while grass cover ranges from 10 to $90 \%$. Annuals are generally absent or have $<5 \%$ cover. Two variations can be distinguished (Table 1c). The first variation occurs at a low altitude $(200-600 \mathrm{~m})$ on deep sandy plains without any rock cover. The second variation occurs at an altitude of 300 to $1000 \mathrm{~m}$ above sea level on level ridges and plains, and in washes with no rock cover or on ridges with a rock cover of 60 to $99 \%$. The first variation of association 8 is dominated by Cladoraphis spinosa (species group W) but Stipagrostis obtusa, Stipagrostis brevifolia and Stipagrostis ciliata (species group X) may be present, while the second variation lacks Cladoraphis spinosa (species group W) and is characterised by Stipagrostis species of species group X (Table 1c).

\section{Mesembryantheceae (HRp359) sp. Ceres Karoo Vygieveld}

A single relevé was surveyed defining this plant association that has not been mapped separately but occurs in isolated patches within subassociation 7.3 in the southern part of the Tanqua Basin on shales of the Ecca Group and tillites of the Dwyka Group. This vygieveld (succulent veld) is found on level ridges with a $99 \%$ cover of small stones. These small black stones and brown chips are responsible for creating a unique microhabitat in which these succulents grow. The succulent and shrub cover is less than $15 \%$, with no grass or annual species present. Species group Y characterises this association (Table 1c).

\section{Pteronia (HRp118) sp. Tanqua Karoo Brackish Flats}

Association 10 occurs in combination with association 7.2 in the Tanqua pan mosaic and is found in the central region of the Tanqua Karoo on alluvial deposits. The alluvial soils are brackish and depending on the salinity of the soils the vegetation differs.
In some areas the pan systems contain no vegetation. This lowlying association occurs on level valley floors or on the edges of the pans. Shrub cover can be as high as 50\% while grasses and annuals are not usually present. Species characterising this association are represented in species group Z (Table 1c).

The three major river systems in the region, namely the Hantam, Tankwa and Doorn Rivers, were not sampled, but were mapped (Fig. 1). These drainage systems occur on Land Type Ia. Many tributaries originating to the northwest of the Hantam Mountain converge to form the Hantam River, which only flows after heavy rains. Patches of Salsola tuberculata and Salsola cf. aphylla dominate this drainage system. Other species include Pentzia incana, Ruschia cradockensis, Atriplex lindleyi, Aridaria noctiflora and Galenia africana. There are numerous flood-irrigated lands as a result of the more favourable water conditions along the drainage system. Other forms of transformation evident are the presence of the invasive alien Prosopis species and the naturalised species Atriplex lindleyi.

The Succulent Karoo vegetation (Acocks 1953, 1988) of the Tankwa and Doorn Rivers comprises species such as Acacia karoo and Malephora crassa, and is usually dominated by Salsola tuberculata. Transformation of the natural vegetation into floodirrigated lands next to these drainage systems has occurred in the past. Few of these lands are still utilised for cropping and now lie barren with limited vegetation cover to combat erosion. The invader Prosopis species is also a serious problem, and has taken over vast areas of these drainage systems.

\section{DISCUSSION}

The clear difference in species composition of the Fynbos related vegetation units and the Succulent Karoo vegetation units was supported by the TWINSPAN on the entire data set of 390 relevés. This difference subsequently led to the final two phytosociological tables and associated maps as discussed in this article and in Van der Merwe et al. (2008). However, since the Hantam-Tanqua-Roggeveld is an area where three biomes meet, namely the Fynbos, Succulent Karoo and Nama Karoo Biomes (Rutherford \& Westfall 1986), it is expected that some vegetation units are transitional between two biomes. For example, Rosenia oppositifolia is a prominent Mountain Renosterveld (Fynbos) related species (Van der Merwe et al. 2008), but it also occurs in the Roggeveld Karoo subassociations 6.2, 6.3 and 6.4 (species group M, Table 1b). Furthermore, Nama Karoo elements such as Euryops multifidus are also found in these subassociations.

While the relationship between the Tanqua Karoo grasslands and grasslands of the Bushmanland, Nama Karoo Biome, was not investigated, common species with a high cover and constancy are found in both areas. Further studies of these affinities are necessary before the relationship between these two areas can be quantified.

Comparisons between previous maps published by Acocks (1953, 1988), Low and Rebelo (1998) and Mucina et al. (2005) show similarities and some interesting dissimilarities. Since the scale of these maps and the current map, and the reasons for compiling the maps, all differ; only generalisations can be made when comparing the various maps. The area covered in the present paper basically includes two of Acocks's veld types (Acocks 1953, 1988). Associations 4 (Escarpment Karoo), 5 (Hantam Karoo) and 6 (Roggeveld Karoo) combined form part of the Western Mountain Karoo (Veld Type 28), which is incorporated into Low and Rebelo's Upland Succulent Karoo (Unit 56) (Low \& Rebelo 1998), while associations 7 (Tanqua and Loeriesfontein Karoo) and 8 (Central Tanqua Grassy Plains) are both included into Acocks's Succulent Karoo (Veld Type 31) (Acocks 1953, 1988), which relates to Low and Rebelo's Lowland 


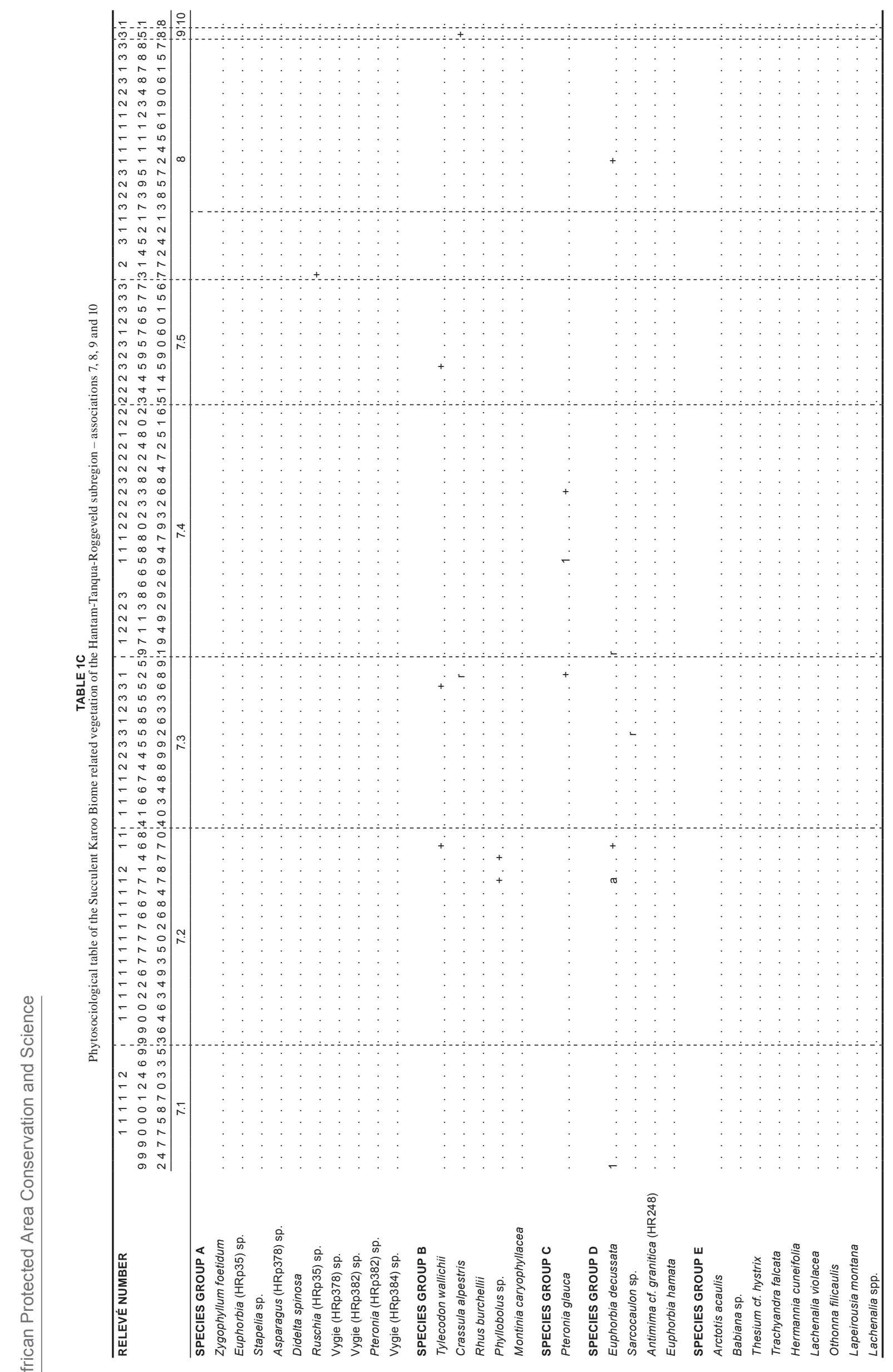




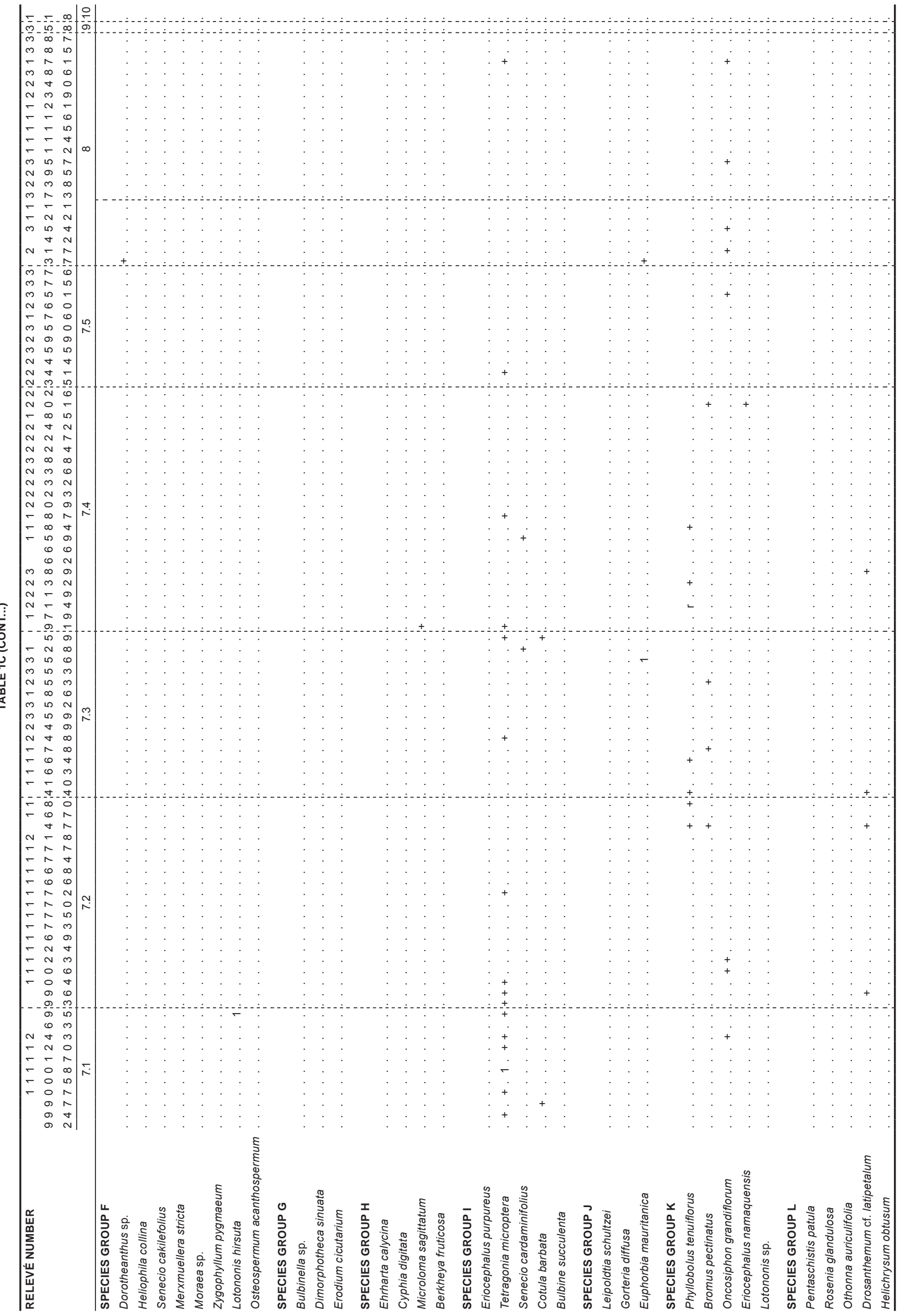




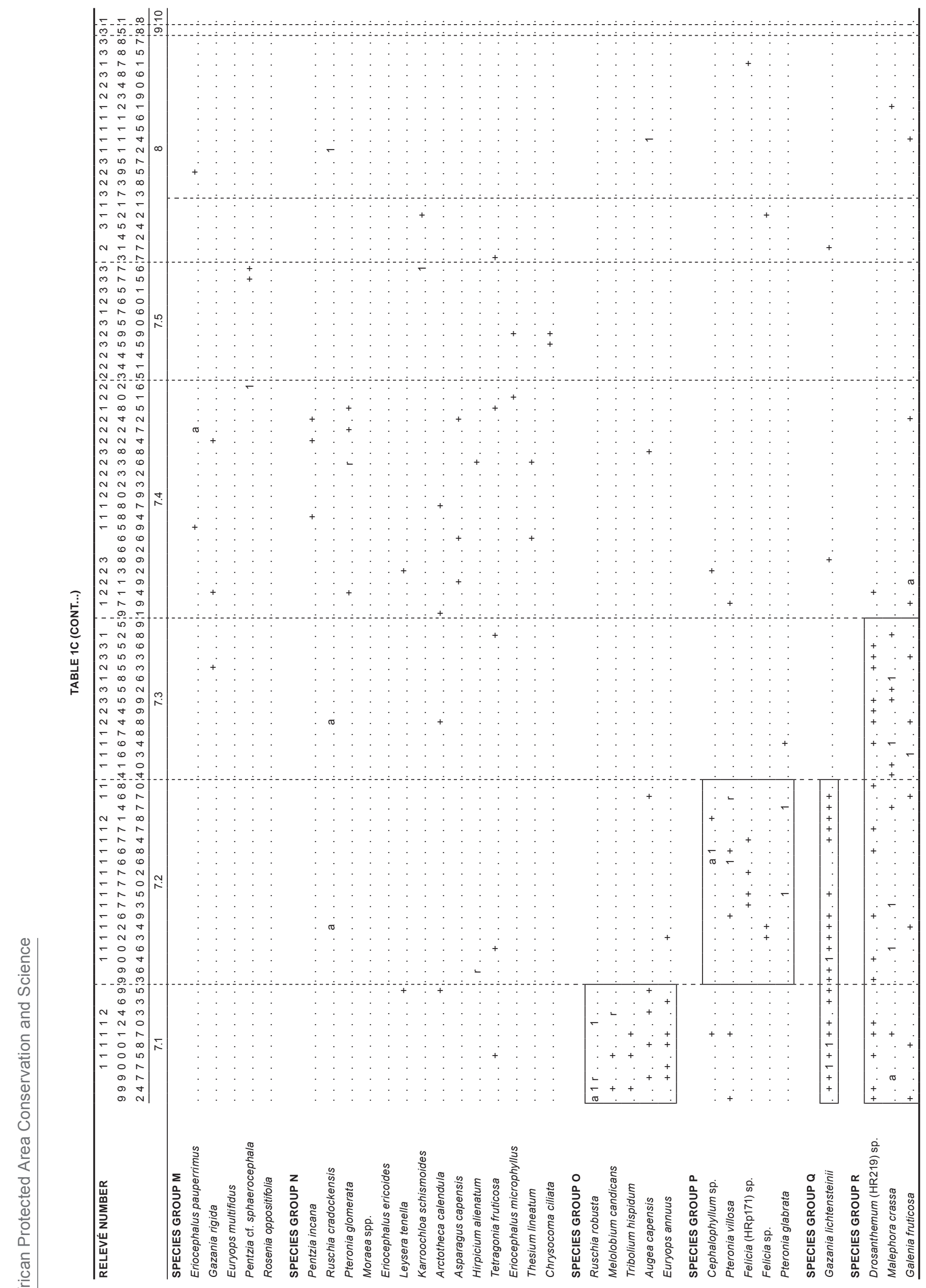




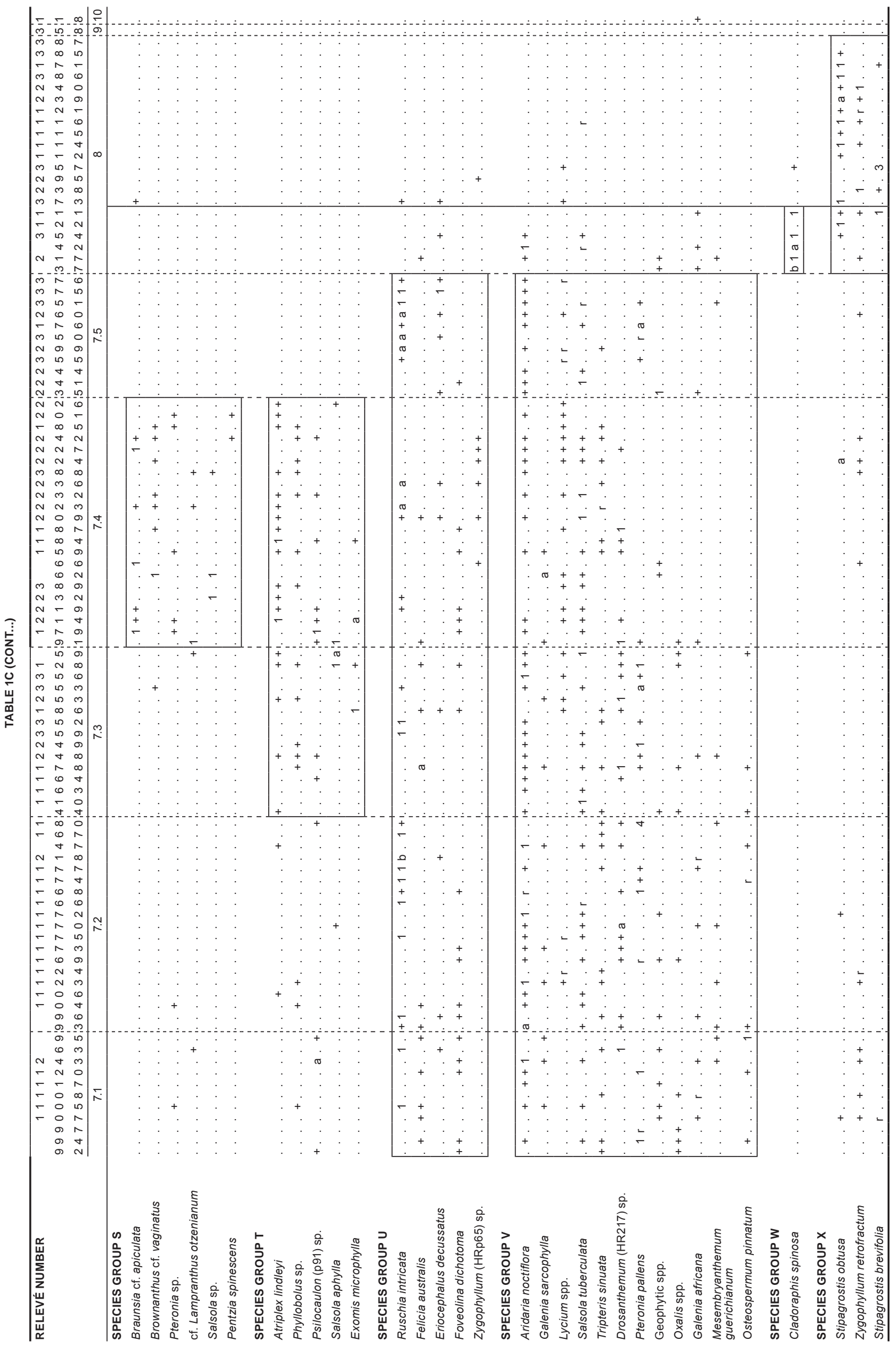




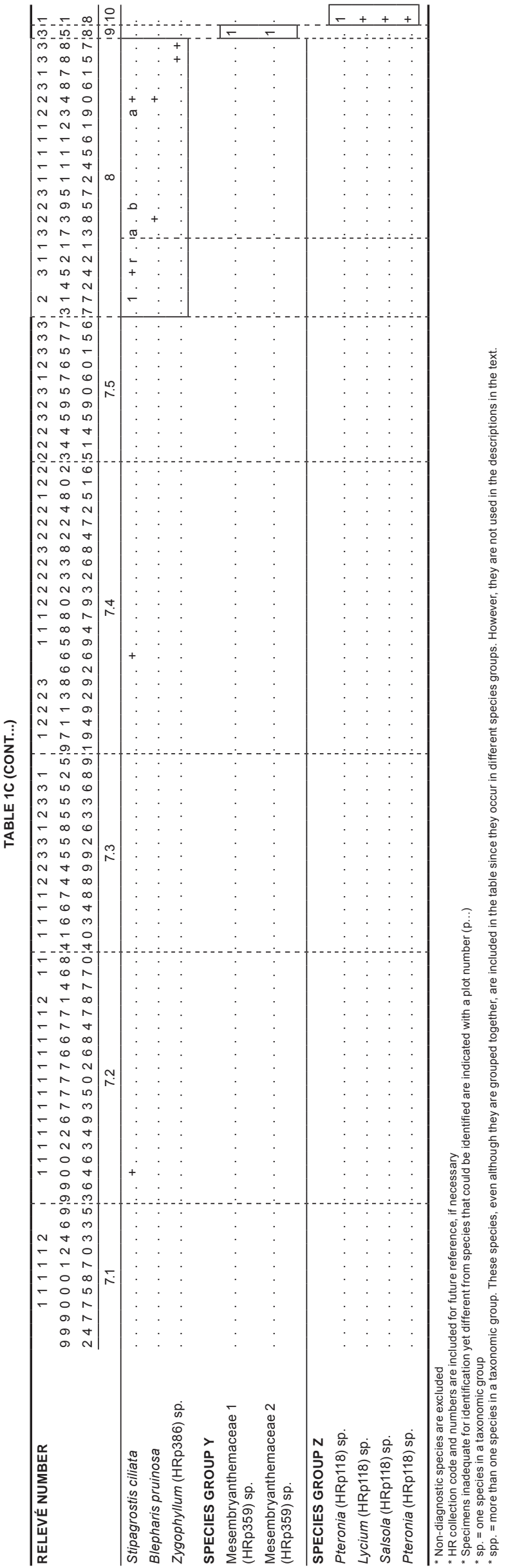

Succulent Karoo (Unit 57) (Low \& Rebelo 1998). Mucina et al. (2005) mapped approximately ten vegetation units within the study area. There is good agreement between association 4 (Escarpment Karoo) and the Tanqua Escarpment Shrubland (SKv 4) of Mucina et al. (2005). In general, the delineation of the Hantam Karoo (association 5), Roggeveld Karoo (association 6) and Tanqua Karoo (association 7) in this study is more restricted than that of the Hantam Karoo (SKt 2), Roggeveld Karoo (SKt 3) and Tanqua Karoo (Skv 5) of Mucina et al. (2005). Comparisons of the Acocks (1953, 1988), Low and Rebelo (1998) and Mucina et al. (2005) maps with the map presented in this article reveal that the maps of Acocks $(1953,1988)$ and Low and Rebelo (1998) differ appreciably in the Van Rhynsdorp/Doorn River region while the Mucina et al. (2005) map is more closely related to the map presented in this paper. The differences in this region require additional study to determine the boundaries of each different vegetation type since the region is situated in the transition between the Tanqua Karoo and Van Rhynsdorp Succulent Karoo and the Fynbos Biome.

In the Sutherland area, the region is classified by Acocks (1953, 1988) as Western Mountain Karoo and by Low and Rebelo (1998) as Upland Succulent Karoo, yet the present study found this vegetation to be more closely related to the Mountain Renosterveld vegetation of the Fynbos Biome, and is described by Van der Merwe et al. (2008) as association 1. Also, north and east of Sutherland, parts of the Mucina et al. (2005) Roggeveld Karoo (SKt3) were incorporated into the Mountain Renosterveld (association 1 in Van der Merwe et al. 2008).

Two major threats to the vegetation in the study area were identified by the farming community and the Northern Cape Department of Agriculture, and through personal observation during field surveys. The first threat is that of invasive alien species, especially Prosopis species. Prosopis glandulosa was introduced to the Karoo to aid in fodder production for small stock in the drier months of the year when little natural vegetation is available (Zimmermann 1991). The pods of these trees are high in protein and many farmers rely on them to carry their stock through the dry months. However, more than one species of Prosopis was introduced and these have now hybridised. These hybrids, with their hybrid strength, have invaded large tracts of land and are now a serious threat in many areas.

Other alien invasive species include Nerium oleander and Nicotiana glauca, which are usually restricted to drainage lines. These species are a serious problem in some areas, although they are not as widespread as the Prosopis species that threaten not only drainage lines but also the natural vegetation between the drainage lines.

The second serious threat is that of less than ideal farming practices. Due to a lack of infrastructure, especially fencing, optimal farm management is not implemented. The main reason for this is that farms in the region have a low income as a result of the unfavourable and harsh environmental conditions. Additionally, the monetary value of the land is low and the cost of infrastructure so high that it is not financially viable for a farmer to invest too much in infrastructure as it will not be possible to recover these costs. There is definitely willingness amongst farmers for improved farm management and infrastructure development; however, their financial means usually do not allow it. Although damage can happen fast, recovery in the Karoo is very slow, because it depends upon unpredictable rainfall events (Esler et al. 2006).

Apart from the transformation as a result of alien invasive vegetation, transformation of natural vegetation into floodirrigated lands next to the major drainage systems has taken place in the past. Few of these lands, especially in the Tanqua 
Karoo, are still utilised for cropping; they now lie barren, with little vegetation cover to combat erosion, or the lands are infested by invasive species, particularly Prosopis species.

Formal conservation within the Hantam-Tanqua-Roggeveld subregion is limited. There are two local municipal reserves, the Nieuwoudtville Wildflower Reserve (115 ha) and the Akkerendam Nature Reserve (230 ha) that qualify as formally protected areas. However, most of the Akkerendam Nature Reserve is located on the plateau of the Hantam Mountain within the Mountain Renosterveld, Fynbos related, vegetation of association 3 (Van der Merwe et al. 2008). The Nieuwoudtville Wildflower Reserve is situated in the Nieuwoudtville mosaic consisting of vegetation units 2.1.1, 2.1.4, 2.2. (Van der Merwe et al. 2008) and 5.1 (Fig.1), which are a combination of Mountain Renosterveld (Fynbos related vegetation) and Succulent Karoo vegetation. The conservation status of the Tanqua Karoo has increased considerably with the expansion of the Tankwa Karoo National Park over the last few years. This National Park currently protects 92495 ha of land; however large tracts thereof are highly degraded. A few private nature reserves and conservancies are also found in the Tanqua Karoo, but these are generally located at the southern end of the Tanqua Basin, closer to Ceres.

In conclusion, this project aimed to classify and describe the vegetation units in the Hantam-Tanqua-Roggeveld subregion using species composition, environmental parameters and vegetation unit relationships to one another to map their geographical distribution. This map could serve as a basis to aid future planning and biodiversity conservation through sustainable land use practices to reduce the impact on the land.

\section{ACKNOWLEDGEMENTS}

The authors would like to thank the Critical Ecosystem Partnership Fund (CEPF) through the SKEP (Succulent Karoo Ecosystem Plan/Program) initiative for funding the project. The Critical Ecosystem Partnership Fund is a joint initiative of Conservation International, the Global Environmental Facility, the Government of Japan, the MacArthur Foundation and the World Bank. Its fundamental goal is to ensure that civil society is engaged in biodiversity conservation. CapeNature, Department of Tourism, Environment and Conservation (Northern Cape) as well as SANParks are thanked for the necessary permits and permission to conduct this research. The Council for Geoscience is thanked for providing geological data of the study area. The assistance of Hennie van den Berg of Iris International for compiling the vegetation map is gratefully acknowledged.

\section{REFERENCES}

Acocks, J.P.H. 1953. Veld types of South Africa. Memoirs of the Botanical Survey of South Africa, 28: 1-192.

Acocks, J.P.H. 1988. Veld types of South Africa. 3rd ed. Memoirs of the Botanical Survey of South Africa, 57: 1-146.

Agricultural Research Council. 1986a. Land type map 3018 Loeriesfontein. Pretoria, Institute for Soil, Climate and Water.

Agricultural Research Council. 1986b. Land type map 3220 Sutherland. Pretoria, Institute for Soil, Climate and Water.

Agricultural Research Council. 1995. Land type map 3118 Calvinia. Pretoria, Institute for Soil, Climate and Water.

Agricultural Research Council. 1999a. Land type map 3120 Williston. Pretoria, Institute for Soil, Climate and Water.

Agricultural Research Council. 1999b. Land type map 3218 Clanwilliam. Pretoria, Institute for Soil, Climate and Water.

Agricultural Research Council. 2002. Land type map 3319 Worcester. Pretoria, Institute for Soil, Climate and Water.
Agricultural Research Council. 2003. Land type map 3320 Ladismith. Pretoria, Institute for Soil, Climate and Water.

Born, J., Linder, H.P. and Desmet, P. 2007. The Greater Cape Floristic Region. Journal of Biogeography, 34: 147-162.

CEPF, 2003. Ecosystem Profile: The Succulent Karoo hotspot, Namibia and South Africa. Critical Ecosystem Partnership Fund report.

Conservation International. 2006. http://www. biodiversityhotspots.org [Accessed 20 February 2006].

Council for Geoscience. 1973. Geological map 3218 Clanwillliam. Pretoria, Council for Geoscience.

Council for Geoscience. 1983. Geological map 3220 Sutherland. Pretoria, Council for Geoscience.

Council for Geoscience. 1989. Geological map 3120 Williston. Pretoria, Council for Geoscience.

Council for Geoscience. 1991. Geological map 3320 Ladismith. Pretoria, Council for Geoscience.

Council for Geoscience. 1997. Geological map 3319 Worcester. Pretoria, Council for Geoscience.

Council for Geoscience. 2001. Geological map 3118 Calvinia. Pretoria, Council for Geoscience.

Council for Geoscience. 2008. Electronic data supplied by the Council for Geoscience, Silverton, Pretoria.

Du Plessis, H.M. 1987. Land Types of the maps 2816 Alexander Bay, 2818 Warmbad, 2916 Springbok, 2918 Pofadder, 3017 Garies, 3018 Loeriesfontein. Memoirs on the Agricultural Natural Resources of South Africa, 9: 1-538.

Esler, K.J., Milton, S.J. \& Dean, W.R.J. 2006. Karoo veld ecology and management. Pretoria, Briza Publications.

Germishuizen, G. \& Meyer, N.L. (eds.). 2003. Plants of southern Africa: An annotated checklist. Strelitzia 14. Pretoria: National Botanical Institute.

Hennekens, S.M. \& Schaminee, J.H.J. 2001. TURBOVEG, a comprehensive data base management system for vegetation data. Journal of Vegetation Science, 12: 589-591.

Hill, M.O. 1979. TWINSPAN - A FORTRAN program for arranging multivariate data in an ordered two-way table by classification of the individuals and attributes. Ithaca, NY, Ecology \& Systematics: Cornell University.

Hilton-Taylor, C. 1994. Western Cape Domain (Succulent Karoo). In Davis, S.D., Heywood, V.H. \& Hamilton, A.C. (eds.), Centres of plant diversity, A guide and strategy for their conservation, volume 1, Cambridge: IUCN Publications Unit, pp. 201-203.

Low, A.B. \& Rebelo, A.G. 1998. Vegetation of South Africa, Lesotho and Swaziland. Pretoria: Department of Environmental Affairs and Tourism.

Mucina, L., Rutherford, M.C. \& Powrie, L.W. (eds). 2005. Vegetation map of South Africa, Lesotho and Swaziland, 1: 1000000 scale sheet maps. Pretoria, South African National Biodiversity Institute.

Nelder V.J., Wilson, B.A., Thompson, E.J. \& Dillewaard, H.A. 2005. Methodology for Survey and Mapping of Regional Ecosystems and Vegetation Communities in Queensland. Version 3.1. Updated September 2005. Brisbane, Queensland Herbarium: Environmental Protection Agency.

Rubidge, B.S. \& Hancox P.J. 1999. The Karoo - a palaeontological wonderland. In: Viljoen, M.J. \& Reimold W.U. An introduction to South Africa's geological and mining heritage. Pretoria: Published by the Geological Society of South Africa and Mintek.

Rubin, F. 1998. The physical environment and major plant communities of the Tankwa Karoo National Park. Koedoe, 41: 61-94.

Rutherford, M.C. \& Westfall, R.H. 1986. Biomes of Southern Africa. An objective characterisation. Memoirs of the Botanical Survey of South Africa, 54: 1-98.

South African National Biodiversity Institute. 2006. http:// www.sanbi.org/consfarm/ [Accessed 2 October 2006].

SA Weather Bureau 1998. Climate of South Africa. Climate statistics up to 1990. WB 42. Pretoria, Government Printer.

Snijman, D. \& Perry, P. 1987. A floristic analysis of the Nieuwoudtville Wild Flower Reserve, north-western Cape. South African Journal of Botany, 53: 445-454. 
Van der Merwe, H., Van Rooyen, M.W. \& Van Rooyen, N. 2008. Vegetation of the Hantam-Tanqua-Roggeveld subregion, South Africa. Part 1. Fynbos Biome related vegetation. Koedoe, 50: 61-71.

Van Wyk, A.E. \& Smith, G.F. 2001. Regions of Floristic Endemism in Southern Africa: A review with emphasis on succulents. Pretoria, Umdaus Press.
Werger, M.J.A. 1974. On concepts and techniques applied in the Zürich-Montpellier method of vegetation survey. Bothalia, 11: 309-323.

Zimmermann, H.G. 1991. Biological control of mesquite, Prosopis spp. (Fabaceae), in South Africa. Agriculture, Ecosystems and Environment, 37: 175-186. 